medRxiv preprint doi: https://doi.org/10.1101/2020.04.27.20079970; this version posted April 29, 2020. The copyright holder for this preprint (which was not certified by peer review) is the author/funder, who has granted medRxiv a license to display the preprint in perpetuity.

All rights reserved. No reuse allowed without permission.

\title{
Eccentric-focused rehabilitation promotes myelin plasticity in individuals with chronic, incomplete spinal cord injury
}

Timothy D. Faw ${ }^{1,2,3}$, Bimal Lakhani ${ }^{4}$, Hanwen Liu' ${ }^{5,6}$, Huyen T. Nguyen 7 , Petra Schmalbrock ${ }^{7}$, Michael V. Knopp ${ }^{7}$, Keith R. Lohse ${ }^{8,9}$, John L.K. Kramer ${ }^{6,10,}$ Dana M. McTigue ${ }^{1,2,11}$, Lara A. Boyd ${ }^{4}$, D. Michele Basso ${ }^{1,2,12 *}$

${ }^{1}$ Neuroscience Graduate Program, The Ohio State University, Columbus, $\mathrm{OH}$ ${ }^{2}$ Center for Brain and Spinal Cord Repair, The Ohio State University, Columbus, $\mathrm{OH}$ ${ }^{3}$ Doctor of Physical Therapy Division, Department of Orthopaedic Surgery, Duke University, Durham, NC

${ }^{4}$ Department of Physical Therapy, University of British Columbia, Vancouver, BC

${ }^{5}$ Department of Physics and Astronomy, University of British Columbia, Vancouver, $\mathrm{BC}$

${ }^{6}$ International Collaboration on Repair Discoveries, University of British Columbia, Vancouver, BC

${ }^{7}$ Department of Radiology, The Ohio State University, Columbus, $\mathrm{OH}$

${ }^{8}$ Department of Health, Kinesiology, and Recreation, University of Utah, Salt Lake City, UT

${ }^{9}$ Department of Physical Therapy and Athletic Training, University of Utah, Salt Lake City, UT

${ }^{10}$ School of Kinesiology, University of British Columbia, Vancouver, BC

${ }^{11}$ Department of Neuroscience, The Ohio State University, Columbus, $\mathrm{OH}$

${ }^{12}$ School of Health and Rehabilitation Sciences, The Ohio State University, Columbus, $\mathrm{OH}$

\section{Author Contact Information:}

Timothy D. Faw, PT, DPT, PhD

Medical Instructor

Duke University

311 Trent Drive

Durham, NC 27710

Phone: (919) 613-8699

Email: timothy.faw@duke.edu

Hanwen Liu, MS

Graduate Research Associate

University of British Columbia

818 W. $10^{\text {th }}$ Ave

Vancouver, BC V6K 1G1

Phone: (604) 675-8876

Email: hwsci@gmail.com
Bimal Lakhani, PhD

Postdoctoral Research Associate

University of British Columbia

2211 Wesbrook Mall

Vancouver, BC V6T 1 Z3

Phone: (604) 822-7197

Email: bimal.lakhani@ubc.ca

Huyen T. Nguyen, $\mathrm{PhD}$

Research Scientist

The Ohio State University

2050 Kenny Rd

Columbus, OH 43221

Phone: (614) 293-2964

Email: nguyen@wcibmi.org 
Petra Schmalbrock, PhD

Associate Professor

The Ohio State University

2050 Kenny Rd

Columbus, $\mathrm{OH} 43221$

Phone:(614) 239-9998

Email: schmalbrock.1@osu.edu

Keith R. Lohse, PhD, PStat

Assistant Professor

University of Utah

250 S. 1850 East

Salt Lake City, UT 84112

Phone: (801) 585-7226

Email: keith.lohse@health.utah.edu

Dana M. McTigue, PhD

Professor

The Ohio State University

460 W. $12^{\text {th }}$ Ave

Columbus, OH 43210

Phone: (614) 292-5523

Email: dana.mctigue@osumc.edu

D. Michele Basso, PT, EdD*

Professor

The Ohio State University

$453 \mathrm{~W} .10^{\text {th }}$ Ave

Columbus, OH 43210

Phone: (614) 366-4559

Email: michele.basso@osumc.edu

*Corresponding Author
Michael V. Knopp, MD, PhD

Professor

The Ohio State University

395 W. $12^{\text {th }}$ Ave

Columbus, OH 43210

Phone: (614) 239-9998

Email: knopp.16@osu.edu

John L. K. Kramer, PhD

Assistant Professor

University of British Columbia

818 W. $10^{\text {th }}$ Ave

Vancouver, BC V6K 1G1

Phone: (604) 675-8876

Email: kramer@icord.org

Lara A. Boyd, PT, PhD

Professor

University of British Columbia

2211 Wesbrook Mall

Vancouver, BC V6T $1 \mathrm{Z3}$

Phone: (604) 822-7197

Email: lara.boyd@ubc.ca

\section{Conflict of Interest Statement:}

The authors have declared that no conflict of interest exists.

\section{Abbreviated Title:}

Myelin plasticity with eccentric training in SCI 


\begin{abstract}
Background: Myelin plasticity has emerged as a novel mechanism by which the nervous system can change with experience, offering new potential for rehabilitation-induced recovery after neurotrauma. This first-in-human study investigated whether innovative, downhill locomotor rehabilitation promotes myelin plasticity in individuals with chronic, incomplete spinal cord injury (SCI).

Methods: Of 20 individuals with SCI that enrolled, 4 passed the imaging screen and had myelin water imaging (MWI) before and after a 12-week (3 times/week) downhill locomotor treadmill training program (SCI+DH). One individual was excluded for imaging artifacts. Uninjured control participants (n=7) had two MWI sessions within the same day. Changes in myelin water fraction (MWF), a histopathologically-validated myelin biomarker, were analyzed in a priori motor learning and non-motor learning brain regions and the cervical spinal cord using statistical approaches appropriate for small sample sizes.
\end{abstract}

Results: Within SCI+DH individuals, significantly more motor learning regions showed increased MWF than non-motor learning regions $(\mathrm{p}<.05)$. Compared to Control, MWF in the SCI+DH group increased in white matter underlying postcentral and precuneus cortices, combined motor learning brain regions, and ventral spinal cord ( $\mathrm{p}<.05)$. To account for small sample size, an estimation-based approach showed the pattern of MWF increase was specific to training and region.

Conclusion: Downhill training increased MWF in brain regions specifically associated with motor learning and in the ventral spinal cord.

Trial Registration: ClincialTrials.gov (NCT02498548, NCT02821845)

Funding: National Institutes of Health [F31NS096921 (TDF), R21HD082808 (DMB)], Craig H. Neilsen Foundation [316282 (DMB)], Foundation for Physical Therapy Research [Promotion of Doctoral Studies Level II Scholarship (TDF)]

Keywords: Spinal Cord Injury, Eccentric, Myelin Plasticity, Locomotion, Rehabilitation 
medRxiv preprint doi: https://doi.org/10.1101/2020.04.27.20079970; this version posted April 29, 2020. The copyright holder for this preprint (which was not certified by peer review) is the author/funder, who has granted medRxiv a license to display the preprint in perpetuity.

\section{Introduction}

Experience-dependent plasticity has primarily focused on neuronal and gray matter changes (1-3). More recently, white matter plasticity emerged as a novel central nervous system (CNS) component of motor learning (4-10). Repetitive activation of neural pathways during motor skill training appears to trigger increased myelin (11). Specifically, activated neurons release neurotransmitters not only at the synaptic cleft, but also along the length of the axon $(12,13)$. These neurotransmitters then bind to receptors on oligodendrocyte progenitor cells causing their proliferation and differentiation into mature, myelinating oligodendrocytes (12-26). In fact, the molecular programs that lead to new oligodendrocytes and myelin formation are activated within hours of motor learning (9) and are ultimately required for motor learning to occur (8). Even small changes in myelination can greatly impact neural network function $(27,28)$, making it especially important in spinal cord injury (SCI) where myelin damage and sensorimotor dysfunction are hallmark features.

To date, most in vivo studies have used diffusion weighted imaging (DWI) to quantify training-induced myelin plasticity, but advances in imaging provides a neurobiologically-specific biomarker of myelin (4-7, 29-31). While DWI detects changes in the microstructural components of white matter (32), the metrics also reflect numerous factors not necessarily related to myelin (33). Alternatively, myelin water imaging (MWI) uses multicomponent T2 relaxation to generate a distribution of $\mathrm{T} 2$ proton relaxation times, which can be separated into three 
distinct components: 1$)$ a short component $(<40 \mathrm{~ms})$ that corresponds to water molecules between the myelin bilayers, 2$)$ an intermediate component ( $~ 80 \mathrm{~ms})$ attributed to intra/extracellular water, and 3) a long component ( $\sim 2 \mathrm{~s})$ corresponding to cerebral spinal fluid $(29,34-37)$. The in vivo measure of myelin, or myelin water fraction (MWF), is derived from the ratio of the short component to the total T2 distribution and demonstrates strong histopathological validity for multiple CNS regions, species, and myelin-related diseases (30, 31, 38-45). Despite its utility, only one study to date has utilized MWI to quantify motor learninginduced myelin plasticity in healthy individuals (10). No studies have used MWF as a biomarker of myelin plasticity in individuals with SCI or in the context of locomotor learning.

Intensive locomotor rehabilitation has shown the most promise for improving functional recovery after SCI, even in the chronic stage (46-53). Yet even after intensive rehabilitation, recovery is often incomplete and significant sensory and motor dysfunction persist (51). Thus, there is an acute need for novel approaches to facilitate motor learning and plasticity. Increasing task complexity produces greater motor learning-related change and relies on both neural and myelin plasticity $(8,54,55)$. In the current study, we increased locomotor complexity by performing treadmill training on a downslope. Downhill walking relies almost entirely on eccentric, or lengthening, muscle contractions (56-58), and produces greater challenge to joint kinetics (58-60), balance and stability (61), and muscle activation $(62,63)$ as compared to walking on level surfaces. Eccentric 
muscle actions require greater neural control than concentric contractions, because precise integration between descending supraspinal motor signals and afferent information from the periphery must occur to achieve efficient motor performance (64). Eccentric training is especially compelling in the context of SCI given that it uniquely increases brain activation in order to inhibit the muscle spindle afferent drive from the stretched muscle to the motor neuron to produce controlled muscle lengthening (64-72). Indeed, downhill walking decreases spinal reflex excitability in healthy individuals (73) and those with multiple sclerosis $(74,75)$. Depressed spinal reflexes have in turn been linked to improved walking function after SCI $(76,77)$. As such, this downhill approach may be particularly suited to better and uniquely engage the CNS and may promote myelin plasticity after SCI. Interestingly, we showed that hindlimb electromyography is normalized during downhill walking in rats with SCI (63). It is unknown whether experience-dependent myelin plasticity occurs after SCI or whether rehabilitation paradigms can promote myelin plasticity in the chronic phase of injury. Therefore, the purpose of this first-in-human study was to investigate the longitudinal changes in brain and spinal cord MWF after a 12week eccentric-focused locomotor training program in individuals with chronic, incomplete SCI. 


\section{Methods}

\section{Study Approval}

This myelin imaging study recruited participants from two ongoing clinical trials designed to investigate the effect of eccentric-focused, downhill training on motor control after SCI (NCT02498548, NCT02821845). All individuals provided informed consent in accordance with the Declaration of Helsinki and all aspects of the study were approved by The Ohio State University's (OSU) Institutional Review Board.

\section{Participants}

Participants with SCI $(n=20)$ were recruited from the primary study and met the following inclusion criteria: age 18 - 85 years old, motor incomplete SCI within C1 - T10, some capacity to step over ground and on a treadmill, had completed an intensive treadmill-based locomotor training program, and were at least 6 months since discharge from outpatient rehabilitation. Exclusion criteria were: lower motor neuron injury innervating the legs, co-existing neurological conditions (i.e. brain injury), cognitive conditions that prevented informed consent, pregnancy, active deep vein thrombosis, skin wounds in regions where harness or hands provide support, or a history of Botox use for spasticity management within the 3 months prior to enrollment. Uninjured control participants $(n=7)$ were recruited from the primary study and the community. All participants completed MRI safety screening. The disposition of participants and reasons for exclusion is shown in Figure 1. See 
medRxiv preprint doi: https://doi.org/10.1101/2020.04.27.20079970; this version posted April 29, 2020. The copyright holder for this preprint (which was not certified by peer review) is the author/funder, who has granted medRxiv a license to display the preprint in perpetuity.

Table 1 for demographics of participants who completed the study and all data processing.

\section{Eccentric-focused Downhill Training Intervention}

The downhill training intervention for participants with SCI began at least 6 months after neurorehabilitation ended (Figure 2). Trainer-assisted downhill stepping occurred 3 times a week for 12 weeks on a $10 \%$ grade, using an instrumented, split-belt treadmill (Bertec; Columbus, $\mathrm{OH}$ ) with custom body-weight support system. Training duration totaled 20 minutes per session, performed in up to 5-minute stepping bouts separated by at least three, 5-minute seated rests. This study design was used as equivalent rest periods can reduce or eliminate delayed onset muscle soreness from downhill eccentric exercise $(78,79)$. Individualized eccentric training complexity occurred by modulating BWS and treadmill walking speed to target frontal plane hip motion or sagittal plane knee motion (80). A team led by a licensed physical therapist in collaboration with up to three clinical rehabilitation assistants provided intermittent manual assistance to allow errorbased motor learning. The objective was self-correction by participants with SCI to attain normal kinematic alignment of the head, trunk, pelvis and legs. Trainers intervened briefly when biomechanical stepping errors predominated. Verbal cues during stepping bouts promoted knowledge of performance, and verbal feedback during rest breaks provided knowledge of results. Verbal cues were structured to facilitate external focus of attention when possible. 


\section{$\underline{\text { MRI Acquisition }}$}

Magnetic resonance (MR) acquisition of the whole brain was performed at the OSU Wright Center for Innovation using a 3-tesla (T) MRI system (Ingenia CX, Philips Healthcare). To acquire images, a dStream head/spine radiofrequency (RF) coil was used. The following scans were collected of the brain: 1) High-resolution 3D fast field echo (FFE) T1-weighted sequence (repetition time (TR) $=9.9 \mathrm{~ms}$, echo time $(\mathrm{TE})=4.6 \mathrm{~ms}$, matrix $=232 \times 192$, in-plane field of view $(\mathrm{FOV})=232 \times 232 \mathrm{~mm}$, slice thickness $=1 \mathrm{~mm}$, number of slices $=150$, number of signal averages $=1$, flip angle $=$ $8^{\circ}$, turbo field echo (TFE) factor $=192$, scan time $=5 \min 20$ sec $)$ and 2) 32-echo gradient and spin echo (GRASE) T2-weighted sequence $(\mathrm{TR}=1200 \mathrm{~ms}, \mathrm{TE}=$ $10,20,30 \ldots, 320 \mathrm{~ms}$, flip angle $=90^{\circ}$, refocusing flip angle $=180^{\circ}$, matrix $=224 \times 90$, in-plane FOV $=224 \times 180 \mathrm{~mm}$, slice thickness $=1.5 \mathrm{~mm}$, number of slices $=80$, number of signal averages $=1$, turbo spin echo factor $=32$, scan time $=9 \mathrm{~min} 30 \mathrm{sec}$ ) .

To acquire images of the cervical spinal cord (C2-C4), the following scans were collected: 1 ) merged fast-field echo (M-FFE) T1-weighted sequence (TR = $650 \mathrm{~ms}$, first TE $=4.1 \mathrm{~ms}$, echo spacing $=7 \mathrm{~ms}$, matrix $=188 \times 188$, in-plane FOV $=150$ $\mathrm{x} 150 \mathrm{~mm}$, slice thickness $=2.5 \mathrm{~mm}$, number of slices $=16$, number of signal averages $=2$, flip angle $=28^{\circ}$, scan time $=4 \mathrm{~min} 10 \mathrm{sec}$ ) and 2) 32-echo GRASE T2-weighted sequence $\left(T R=1500 \mathrm{~ms}, \mathrm{TE}=\mathrm{n}^{*} 10 \mathrm{~ms}\right.$, flip angle $=90^{\circ}$, refocusing flip angle $=180^{\circ}$, matrix $=240 \times 196$, in-plane FOV $=180 \times 147 \mathrm{~mm}$, slice thickness $=2.5 \mathrm{~mm}$, number 
of slices $=16$, number of signal averages $=1$, TSE factor $=32$, scan time $=9 \mathrm{~min}$ 10sec).

For individuals with SCI, MRI-acquisition occurred within 6 weeks prior to downhill training (range $=3 \mathrm{~d}$ to $39 \mathrm{~d}$ ) and within 24 hours of the final training session. For test-retest reliability in uninjured control participants, scans of the brain and spinal cord were performed back-to-back, separated by changing of RF coils. The participants were then allowed to adjust positioning before the retest condition.

\section{Generation of MWF Maps}

Generation of brain and spinal cord MWF maps from T2 relaxation imaging used the latest non-negative least squares method (35), implemented with an extended phase graph algorithm to correct for the stimulated echoes (29). The T2 distribution of each imaging voxel was partitioned into short $(<40 \mathrm{~ms})$, intermediate (40-200ms), and long (>1500ms) components using an in-house MATLAB code (MATLAB R2013b, MathWorks Inc) developed by collaborators at the University of British Columbia (code can be requested from https://mriresearch.med.ubc.ca/news-projects/myelin-water-fraction/). In this method, the short component corresponds to water molecules between myelin bilayers $(35,81)$. The MWF was defined as the sum of the amplitudes within the short T2 component divided by the amplitude sum of the total T2 distribution. Voxel-based MWF maps were generated for each participant. 
medRxiv preprint doi: https://doi.org/10.1101/2020.04.27.20079970; this version posted April 29, 2020. The copyright holder for this preprint (which was not certified by peer review) is the author/funder, who has granted medRxiv a license to display the preprint in perpetuity.

\section{Processing of Brain Imaging}

Further processing of brain MR data was performed as previously described by Lakhani et al (82). Here, we utilized the freely available FreeSurfer Software Suite v5.3 (https://surfer.nmr.mgh.harvard.edu/) to perform all morphometric procedures, including automated cortical reconstruction and volumetric segmentation. The technical details of these procedures have been described previously (82-92). Briefly, this processing included motion correction and averaging (90) of multiple volumetric T1 weighted images, removal of non-brain tissue using a hybrid watershed/surface deformation procedure (88), automated Talairach transformation, segmentation of the subcortical white matter and deep gray matter volumetric structures (including hippocampus, amygdala, caudate, putamen, ventricles) $(86,87)$, intensity normalization (93), tessellation of the gray matter white matter boundary, automated topology correction $(85,94)$, and surface deformation following intensity gradients to optimally place the gray/white and gray/cerebrospinal fluid borders at the location where the greatest shift in intensity defines the transition to the other tissue class $(83,84,95)$. Images were automatically processed with the longitudinal stream (91). Specifically an unbiased within-subject template space and image was created using robust, inverse consistent registration (90). Several processing steps, such as skull stripping, Talairach transforms, atlas registration as well as spherical surface maps and parcellations were then initialized with common information from the withinsubject template, significantly increasing reliability and statistical power (91). 
medRxiv preprint doi: https://doi.org/10.1101/2020.04.27.20079970; this version posted April 29, 2020. The copyright holder for this preprint (which was not certified by peer review) is the author/funder, who has granted medRxiv a license to display the preprint in perpetuity.

All rights reserved. No reuse allowed without permission.

Visual inspection of FreeSurfer surface reconstructions occurred at each stage of the longitudinal processing pipeline. Manual correction of errors included removing dura misidentified as cortex and re-processing the current and subsequent steps.

Linear co-registration occurred in three steps, using established methods by Lakhani et al (82) and Deoni et al (92): 1) registration of the first echo from the T2 scan to the MWF map, 2) registration of the first echo of the T2 scan to the parcellated T1 anatomy, and 3) registration of the MWF map to the parcellated anatomy. Importantly, all processing occurred on the same workstation, using the same software version (96) and individualized intensity normalization was used to increase registration accuracy (93). The FreeSurfer-generated white matter parcellation map (89) was used to extract mean MWF from a priori identified regions of interest (ROI).

\section{Processing of Spinal Cord Imaging}

Post-processing of spinal cord MR data was performed as described by Liu et al (97). Spinal cord segmentation of the GRASE image occurred using the Spinal Cord Toolbox PropSeg tool $(98,99)$, which generated a mask of the whole cord. For segmentation, we used the $16^{\text {th }}$ echo of the GRASE image because it has the greatest contrast between the spinal cord and cerebrospinal fluid. Visual inspections occurred and manual corrections to the mask were made when needed. The whole cord mask was then registered to the PAM50 template (100) using a nonlinear transformation that involved a combination of center of mass rotation, affine, 
medRxiv preprint doi: https://doi.org/10.1101/2020.04.27.20079970; this version posted April 29, 2020. The copyright holder for this preprint (which was not certified by peer review) is the author/funder, who has granted medRxiv a license to display the preprint in perpetuity.

All rights reserved. No reuse allowed without permission.

symmetric normalization, and bsplinesyn algorithms. This process obtained the warping functions used to transform the GRASE images and subsequently MWF maps into the template space. Visual inspection of all registered images occurred. MWF values were extracted from the PAM50 atlas labels.

\section{$\underline{\text { Analysis and Statistics }}$}

For analysis of brain MWF data, subcortical white matter regions corresponding to areas known to be responsive to motor learning were identified $a$ priori. Motor learning areas included white matter underlying the precentral, postcentral, paracentral, caudal middle frontal, superior frontal, inferior parietal, and precuneus cortices, and the anterior and posterior regions of the corpus callosum (CC) (101). Regions not expected to change following an eccentric-focused locomotor task were also identified a priori. Non-motor learning brain regions included white matter underlying the fusiform, inferior temporal, lateral occipital, middle temporal, superior temporal, lateral orbitofrontal, lateral occipital, and lingual cortices (101). Due to the bilateral nature of the locomotor task, MWF data from right and left ROI's were combined and averaged to calculate on overall MWF value for each region. Within-session test-retest reliability was calculated from all uninjured control participants for all motor learning regions and three out of the seven non-motor learning regions (lateral occipital, lateral orbitofrontal, and lingual). Missing temporal lobe imaging data was identified on the GRASE scan of three healthy control individuals that affected the fusiform, inferior temporal, 
medRxiv preprint doi: https://doi.org/10.1101/2020.04.27.20079970; this version posted April 29, 2020. The copyright holder for this preprint (which was not certified by peer review) is the author/funder, who has granted medRxiv a license to display the preprint in perpetuity.

All rights reserved. No reuse allowed without permission.

middle temporal, and superior temporal regions. Thus, test-retest reliability was determined in these regions using data from $n=4$ uninjured control participants without data loss. The intraclass correlation coefficient (ICC) was determined in all ROI's. Regions with poor reliability, based on ICC values $<0.5$, were excluded from subsequent analyses (102).

To determine whether individual MWF changes could be interpreted as exceeding measurement error (103), we calculated the minimal detectable change (MDC) for each ROI using the formula MDC $=S D * \sqrt{ }(1-r) * 1.96$ as described by Forrest et al (104). Here, SD represents the standard deviation of the difference between pre- and post-intervention measurements, $r$ represents the ICC, and 1.96 is the $97.5 \%$ quantile of the standard normal distribution of a two-tailed test with the significance set at .05. Fisher's exact test was used to determine whether motor learning regions were more or less likely to demonstrate increases exceeding the MDC.

For cohort analyses, we compared the mean percent change of the downhill trained SCI participants $(\mathrm{SCI}+\mathrm{DH})$ with the mean percent change of the test-retest data in the uninjured control group (Control) using a Mann Whitney U, nonparametric test to determine whether the mean percent MWF change within each ROI for the SCI+DH group exceeded the variability of the measure established by the Control group. Further, to account for the small number of subjects with SCI, we employed an estimation-based method of analysis that focuses on effect size. Using the $95 \%$ confidence intervals (CI), the mean percent change within a priori 
medRxiv preprint doi: https://doi.org/10.1101/2020.04.27.20079970; this version posted April 29, 2020. The copyright holder for this preprint

(which was not certified by peer review) is the author/funder, who has granted medRxiv a license to display the preprint in perpetuity.

All rights reserved. No reuse allowed without permission.

defined motor learning regions were contrasted against two sets of control regions: non-motor regions within the same SCI participant (within group) and homologous motor regions in uninjured control participants (between group). Change data from each ROI were pooled to determine an overall percent change for motor learning and non-motor learning regions. Here, we calculated a weighted mean and 95\% CI based on the number of data points each individual contributed to the average to account for missing data from three uninjured control participants. 
medRxiv preprint doi: https://doi.org/10.1101/2020.04.27.20079970; this version posted April 29, 2020. The copyright holder for this preprint (which was not certified by peer review) is the author/funder, who has granted medRxiv a license to display the preprint in perpetuity.

\section{Results}

\section{$\underline{\text { Reliability of MWF Measures }}$}

In past research, myelin water imaging showed significant variation in MWF values across control white matter regions (105), but had good reliability for testretest (10,106-109), between vendors (110) and facilities (111), and across field strengths (112). To determine the stability of MWF values at our OSU facility, we measured the within-session test-retest reliability of the MWF signal in uninjured control participants. Two motor learning regions (paracentral and superior frontal) had poor single-session test-retest reliability and were excluded from further analyses. Moderate to excellent reliability of MWF occurred for remaining ROIs (ICC range: 0.503-0.907; Table 2). Spinal cord ROIs had good to excellent test-retest reliability of MWF values (ICC range: $0.814-0.917$; Table 2).

\section{Minimal Detectable Change between MWF Measures}

To determine whether individual, pre-post changes in MWF were likely to exceed measurement error (104), we calculated the MDC. In brain regions, MDCs ranged from 0.0032 in the middle temporal region to 0.0122 in the posterior corpus callosum (Table 3). Greater MDC variability occurred in spinal cord regions, ranging from 0.0028 in the whole cord to 0.0389 in the lateral funiculi (Table 3). 
medRxiv preprint doi: https://doi.org/10.1101/2020.04.27.20079970; this version posted April 29, 2020. The copyright holder for this preprint (which was not certified by peer review) is the author/funder, who has granted medRxiv a license to display the preprint in perpetuity.

\section{Downhill Training Increases Brain MWF in Individuals with Chronic SCI}

Individual responses to downhill training were determined by comparing pre-training MWF values in motor learning and non-motor brain regions with those post-training. Participant SCI-01 had greater MWF after downhill training that exceeded the MDC in 6 out of 7 motor learning regions, with several regional increases being substantial and the smallest remaining above 10\% (Fig. 3). Substantial increases of $26 \%$ for sensory, $33 \%$ for motor and $40 \%$ in caudal middle frontal regions were observed. Conversely, 1 non-motor learning region showed an increase and 1 showed a decrease in MWF that exceeded the MDC after training. Participant SCI-02 had MWF increases exceeding the MDC across 6 out of 7 brain motor learning regions after downhill training (Fig. 3). The largest increase occurred in the anterior corpus callosum (24\%), followed by precuneus (22\%) and posterior corpus callosum (20\%). In non-motor learning regions for SCI-02, MWF increased (lingual region) and decreased (lateral orbitofrontal region) beyond MDC.

Participant SCI-03 showed the fewest brain changes in response to downhill training (Fig. 3). For this participant, MWF increased in 2 of 7 motor learning regions and decreased in 1 of 7 non-motor learning regions relative to MDC after training. The greatest increase in MWF occurred in the posterior corpus callosum (12\%), followed by postcentral (10\%).

A Fisher's exact test demonstrated that significantly more brain regions associated with motor learning showed increases in MWF in our group of SCI participants as compared to non-motor learning areas. (Fig. 4; $p=.0003$ ). 
medRxiv preprint doi: https://doi.org/10.1101/2020.04.27.20079970; this version posted April 29, 2020. The copyright holder for this preprint (which was not certified by peer review) is the author/funder, who has granted medRxiv a license to display the preprint in perpetuity.

\section{Downhill Training Promotes Myelin Plasticity in Brain Motor Learning Regions}

To determine whether group MWF changes exceeded measurement variability, we compared the average percent change between pre- and posttraining values in the SCI+DH group with the test-retest percent change values in uninjured control participants (Fig. 5). The SCI+DH group had significantly greater MWF than Control in 2 of 7 motor learning regions (postcentral, $p=.0167$; and precuneus, $\mathrm{p}=.0167)$. Similarly, the SCI+DH group showed greater combined percent change across all motor learning regions as compared to non-motor learning areas $(p=.033)$. No between-group differences in MWF occurred in any of the non-motor learning regions ( $\mathrm{p}>.05)$.

\section{Downhill Training Increases Ventral Funiculus MWF in Individuals with SCI}

Individual white matter plasticity responses in the cervical spinal cord were also identified by comparing pre- and post-training MWF values in major white matter funiculi (Fig. 6). The MWF tended to decrease in the dorsal columns of all three participants and exceeded the MDC for SCI-01. Conversely, MWF increased in the ventral funiculi of all three participants and in 2 of 3 participants exceeded the MDC. Individual MWF changes in the lateral funiculi and the whole spinal cord failed to surpass the MDC.

We compared the mean percent change in values between the SCI+DH cohort and test-retest percent change scores for the Control group for all spinal cord ROI's (Fig. 7). The MWF increase in the ventral funiculi of SCI individuals post downhill 
medRxiv preprint doi: https://doi.org/10.1101/2020.04.27.20079970; this version posted April 29, 2020. The copyright holder for this preprint (which was not certified by peer review) is the author/funder, who has granted medRxiv a license to display the preprint in perpetuity.

All rights reserved. No reuse allowed without permission.

was significantly greater than measurement variability of the control group $(p=.033)$ but the decrease of MWF in the dorsal columns was not different between groups.

\section{Myelin Plasticity is Specific to Training and Region}

To account for the small number of subjects with SCI, we used an estimationbased approach to determine effects of downhill training on myelin plasticity in the brain and spinal cord. In the brain, there was a positive, rightward shift in MWF CI for 6 of 7 motor learning regions following downhill training. Clustering at the zero line for MWF values in non-motor regions within individuals with SCI and in motor learning and non-motor learning regions of uninjured control participants (Fig. 8) indicate that downhill training did not induce generalized brain myelin responses.

A spatially-distinct pattern also emerged in individuals with SCI as noted by a rightward shift in MWF CI in the ventral funiculi but a leftward shift in the dorsal columns. No pattern was present in the spinal cord of uninjured control participants (Fig. 9). 
medRxiv preprint doi: https://doi.org/10.1101/2020.04.27.20079970; this version posted April 29, 2020. The copyright holder for this preprint (which was not certified by peer review) is the author/funder, who has granted medRxiv a license to display the preprint in perpetuity.

All rights reserved. No reuse allowed without permission.

\section{Discussion}

Our results provide the first evidence of training-induced white matter plasticity in the brain and spinal cord of individuals with chronic, incomplete SCI. Importantly, MWF increases occurred in CNS regions primarily associated with motor learning and descending motor control. These findings extend previous rodent and human studies that show learning-induced white matter plasticity after complex motor task training (4-10). Here, we provide the first evidence of myelinspecific changes in the brain following a complex locomotor learning task.

Downhill training was predicted to spark an adaptive myelin response via release of neuroactive molecules, such as glutamate, along neurally-activated axons (12-22, 24-26). Adaptive myelination in response to neurotransmitters relies on differentiation of new oligodendrocytes (113). In rodents with SCI, some oligodendrocyte progenitor cell proliferation and differentiation occurs at the injury site (114-122) but whether rehabilitation training produces further gains is unknown. There are opportunities for new myelin to be added in response to training. First, gaps in myelin have been identified in the normal CNS which differs from the classic view of regularly spaced myelin nodes extending the full length of the axon $(123,124)$. Second, SCI reduces myelin below the injury as measured by MWF in rodents (44). Adding new myelin at these gaps and in areas of decreased myelin will speed up neural signaling and contribute to synaptic strengthening, a key component of motor learning (125). 
Brain regions that responded to eccentric training occurred specifically in motor learning areas (i.e. white matter underlying primary motor/sensory, motor planning, and visuomotor association cortices). These motor learning regions are preferentially activated by and receive greater afferent feedback during eccentric contractions $(67-71,126)$. Increased MWF in the caudal middle frontal region after training in two out of three individuals with SCI highlights the cognitive demand on task performance and is indicative of early motor learning $(127,128)$. Indeed, individuals with SCI report having to consciously "think about" every aspect of every step and depend on vision when walking $(129,130)$. Visuomotor association areas, particularly the posterior corpus callosum, showed the most consistent MWF increases across individuals with SCI. These were unexpected changes given that downhill training avoided the use of mirrors and downward gaze. Perhaps the increased myelin in visual regions reflects motor learning effects off the treadmill during daily walking. Interestingly, virtual reality training for the lower extremities after SCI resulted in a different pattern of white matter changes, supporting that adaptive myelin plasticity is highly task specific (131). Taken together, our data support and extend past work highlighting the increased role of the brain in controlling locomotion after SCI. It will be important for future studies to perform MWI at multiple time points before, during, and after training to better understand the timing of MWF change in various brain regions and determine whether increases are maintained over time. 
medRxiv preprint doi: https://doi.org/10.1101/2020.04.27.20079970; this version posted April 29, 2020. The copyright holder for this preprint (which was not certified by peer review) is the author/funder, who has granted medRxiv a license to display the preprint in perpetuity.

In the spinal cord, one individual (SCI-01) had increased MWF in the ventral funiculi but decreased MWF in the dorsal column sensory tract that exceeded the MDC (Fig. 3). The other two participants with SCI demonstrated this pattern although to a lesser extent. The concept of a training-induced decrease in MWF is interesting, as thinning of the myelin sheath by perinodal astrocytes was recently identified as a mechanism to finely tune conduction velocity and spike-time arrival (132). That myelin thickness could be increased or decreased to alter neural circuit synchrony during motor learning raises numerous questions about the type, timing, and sequence of rehabilitation approaches to maximize plasticity and function after CNS trauma. For instance, locomotor training on a flat treadmill, which was a prerequisite for participation, is a well-established model for sensory-driven locomotion via central pattern generator activation (133-138). Meanwhile, axons in the ventral spinal cord are major targets for collateral sprouting from supraspinal axons as they attempt to bypass the lesion (139) and are closely related to locomotor control after SCI (140-142). As such, the observed tendency for a decrease in dorsal column MWF alongside a concomitant increase in ventral MWF observed here could suggest a training-induced shift from sensory driven locomotion to more integrated control with greater input from descending systems.

An important aspect of the increased MWF with eccentric training is that it occurred at such substantial SCI chronicity - more than 40 years in two individuals. Thus, the potential for locomotor-dependent myelin plasticity may persist indefinitely after SCI. Based on animal SCI models, we presume that this plasticity 
reflects new motor learning given that neither general activity nor performing a previously learned task induced white matter plasticity (8). Importantly, this implies that eccentric motor control may not be trained by conventional treadmillbased rehabilitation or by living with SCI. Future studies into the evolution of myelin plasticity after SCI and with various rehabilitation approaches will add clarity.

An obvious limitation of this study is the small sample size. Spine hardware, claustrophobia, and motion artifact are MRI-specific complications encountered here. In future studies, interference by hardware can be minimized by adjusting MRI collection parameters to enable greater participation in imaging. In acknowledgement of the low number, we used within-subject brain regions as negative controls and statistical approaches appropriate for low sample sizes (MDC, confidence intervals, nonparametrics). The concurrence across individuals and positive myelin responses in a priori brain regions offers some confidence that our findings here might generalize to larger groups. Consideration of MWF as a measure of adaptive myelin after SCI carries risks that part of the value reflects iron content (143). We believe these risks are very low since these sequala will have resolved in chronic SCI. Also, MWF values agree well with histopathologically identified myelin $(30,31,38-45)$. Even so, MWF cannot differentiate between the mechanisms of myelin plasticity such as de novo myelination by newly formed oligodendrocytes, new myelin internodes, increased internode length, or increased myelin thickness. While a combination of these mechanisms is likely involved in training-induced myelin plasticity, elegant work conducted in mice $(8,26)$ along with our own 
preclinical work (data not shown) indicate that new myelin produced by newly differentiated oligodendrocytes play a role.

Overall, these data are the first to show white matter plasticity in individuals with SCI and in response to a locomotor intervention. Even though from a small sample, these data are compelling and suggest that myelin is modulated by experience decades after SCI. Consideration of white matter plasticity as a relevant parameter in recovery of function is warranted. Future studies that establish the rate and extent of adaptive myelination in SCI are necessary to maximize recovery potential. 
medRxiv preprint doi: https://doi.org/10.1101/2020.04.27.20079970; this version posted April 29, 2020. The copyright holder for this preprint (which was not certified by peer review) is the author/funder, who has granted medRxiv a license to display the preprint in perpetuity.

All rights reserved. No reuse allowed without permission.

\section{Acknowledgements}

This work was funded by the National Institutes of Health [F31NS096921 (TDF), R21HD082808 (DMB)] and the Craig H. Neilsen Foundation [316282 (DMB)]. TDF was

also supported by a Promotion of Doctoral Studies Level II Scholarship from the Foundation for Physical Therapy Research. 
medRxiv preprint doi: https://doi.org/10.1101/2020.04.27.20079970; this version posted April 29, 2020. The copyright holder for this preprint (which was not certified by peer review) is the author/funder, who has granted medRxiv a license to display the preprint in perpetuity.

All rights reserved. No reuse allowed without permission.

\section{Author Contributions}

TDF, DMB, LAB, and DMM designed the study. TDF and DMB led downhill training sessions for individuals with SCI. TDF, HTN, PS, and MVK collected the magnetic resonance imaging data. TDF, BL, and HL processed the data. TDF, BL, HL, KRL, JLKK, LAB, and DMB analyzed and interpreted the data. TDF wrote the first and final drafts of the manuscript and prepared the figures, under the guidance of DMB. DMB wrote portions of the introduction and discussion. All authors edited the manuscript and approved the final version. 


\section{Bibliography}

1. Kleim JA, and Jones TA. Principles of experience-dependent neural plasticity: implications for rehabilitation after brain damage. J Speech Lang Hear Res. 2008;51(1):S225-39.

2. Fouad K, and Tetzlaff W. Rehabilitative training and plasticity following spinal cord injury. Exp Neurol. 2012;235(1):91-9.

3. Nudo RJ. Recovery after brain injury: mechanisms and principles. Front Hum Neurosci. 2013;7:887.

4. Scholz J, Klein MC, Behrens TE, and Johansen-Berg H. Training induces changes in white-matter architecture. Nat Neurosci. 2009;12(11):1370-1.

5. Hofstetter S, Tavor I, Tzur Moryosef S, and Assaf Y. Short-term learning induces white matter plasticity in the fornix. $J$ Neurosci. 2013;33(31):12844-50.

6. Sampaio-Baptista C, Khrapitchev AA, Foxley S, Schlagheck T, Scholz J, Jbabdi $\mathrm{S}$, et al. Motor skill learning induces changes in white matter microstructure and myelination. J Neurosci. 2013;33(50):19499-503.

7. Borich MR, Brown KE, and Boyd LA. Motor skill learning is associated with diffusion characteristics of white matter in individuals with chronic stroke. $J$ Neurol Phys Ther. 2014;38(3):151-60.

8. McKenzie IA, Ohayon D, Li H, de Faria JP, Emery B, Tohyama K, et al. Motor skill learning requires active central myelination. Science. 2014;346(6207):31822. 
9. Xiao L, Ohayon D, McKenzie IA, Sinclair-Wilson A, Wright JL, Fudge AD, et al. Rapid production of new oligodendrocytes is required in the earliest stages of motor-skill learning. Nat Neurosci. 2016;19(9):1210-7.

10. Lakhani B, Borich MR, Jackson JN, Wadden KP, Peters S, Villamayor A, et al. Motor skill acquisition promotes human brain myelin plasticity. Neural Plast. 2016;2016:7526135.

11. Fields RD. A new mechanism of nervous system plasticity: activity-dependent myelination. Nat Rev Neurosci. 2015;16(12):756-67.

12. Kukley M, Capetillo-Zarate E, and Dietrich D. Vesicular glutamate release from axons in white matter. Nat Neurosci. 2007;10(3):311-20.

13. Ziskin JL, Nishiyama A, Rubio M, Fukaya M, and Bergles DE. Vesicular release of glutamate from unmyelinated axons in white matter. Nat Neurosci. 2007;10(3):321-30.

14. Barres BA, and Raff MC. Proliferation of oligodendrocyte precursor cells depends on electrical activity in axons. Nature. 1993;361(6409):258-60.

15. Borges K, Ohlemeyer C, Trotter J, and Kettenmann H. AMPA/kainate receptor activation in murine oligodendrocyte precursor cells leads to activation of a cation conductance, calcium influx and blockade of delayed rectifying $\mathrm{K}+$ channels. Neuroscience. 1994;63(1):135-49.

16. Demerens C, Stankoff B, Logak M, Anglade P, Allinquant B, Couraud F, et al. Induction of myelination in the central nervous system by electrical activity. Proc Natl Acad Sci U S A. 1996;93(18):9887-92. 
17. Stevens B, Tanner S, and Fields RD. Control of myelination by specific patterns of neural impulses. J Neurosci. 1998;18(22):9303-11.

18. Barres BA, and Raff MC. Axonal control of oligodendrocyte development. J Cell Biol. 1999;147(6):1123-8.

19. Bergles DE, Roberts JD, Somogyi P, and Jahr CE. Glutamatergic synapses on oligodendrocyte precursor cells in the hippocampus. Nature. 2000;405(6783):187-91.

20. Lin SC, and Bergles DE. Physiological characteristics of NG2-expressing glial cells. J Neurocytol. 2002;31(6-7):537-49.

21. Stevens B, Porta S, Haak LL, Gallo V, and Fields RD. Adenosine: a neuron-glial transmitter promoting myelination in the CNS in response to action potentials. Neuron. 2002;36(5):855-68.

22. Lin SC, and Bergles DE. Synaptic signaling between GABAergic interneurons and oligodendrocyte precursor cells in the hippocampus. Nat Neurosci. $2004 ; 7(1): 24-32$.

23. Gallo V, Mangin JM, Kukley M, and Dietrich D. Synapses on NG2-expressing progenitors in the brain: multiple functions? J Physiol. 2008;586(16):3767-81.

24. Hamilton N, Hubbard PS, and Butt AM. Effects of glutamate receptor activation on NG2-glia in the rat optic nerve. J Anat. 2009;214(2):208-18.

25. Malone M, Gary D, Yang IH, Miglioretti A, Houdayer T, Thakor N, et al. Neuronal activity promotes myelination via a cAMP pathway. Glia. 2013;61(6):843-54. 
26. Gibson EM, Purger D, Mount CW, Goldstein AK, Lin GL, Wood LS, et al. Neuronal activity promotes oligodendrogenesis and adaptive myelination in the mammalian brain. Science. 2014;344(6183):1252304.

27. Pajevic S, Basser PJ, and Fields RD. Role of myelin plasticity in oscillations and synchrony of neuronal activity. Neuroscience. 2014;276:135-47.

28. Fields RD, Woo DH, and Basser PJ. Glial Regulation of the Neuronal Connectome through Local and Long-Distant Communication. Neuron. $2015 ; 86(2): 374-86$

29. Prasloski T, Rauscher A, MacKay AL, Hodgson M, Vavasour IM, Laule C, et al. Rapid whole cerebrum myelin water imaging using a 3D GRASE sequence. Neuroimage. 2012;63(1):533-9.

30. Laule C, Leung E, Lis DK, Traboulsee AL, Paty DW, MacKay AL, et al. Myelin water imaging in multiple sclerosis: quantitative correlations with histopathology. Mult Scler. 2006;12(6):747-53.

31. Laule C, Kozlowski P, Leung E, Li DKB, Mackay AL, and Moore GRW. Myelin water imaging of multiple sclerosis at $7 \mathrm{~T}$ : correlations with histopathology. NeuroImage. 2008;40(4):1575-80.

32. Gulani V, Webb AG, Duncan ID, and Lauterbur PC. Apparent diffusion tensor measurements in myelin-deficient rat spinal cords. Magn Reson Med. 2001;45(2):191-5.

33. Alexander AL, Lee JE, Lazar M, and Field AS. Diffusion tensor imaging of the brain. Neurotherapeutics. 2007;4(3):316-29. 
34. MacKay A, Whittall K, Adler J, Li D, Paty D, and Graeb D. In vivo visualization of myelin water in brain by magnetic resonance. Magn Reson Med. 1994;31(6):673-7.

35. Whittall KP, MacKay AL, Graeb DA, Nugent RA, Li DK, and Paty DW. In vivo measurement of T2 distributions and water contents in normal human brain. Magn Reson Med. 1997;37(1):34-43.

36. MacKay A, Laule C, Vavasour I, Bjarnason T, Kolind S, and Madler B. Insights into brain microstructure from the T2 distribution. Magn Reson Imaging. 2006;24(4):515-25.

37. Alonso-Ortiz E, Levesque IR, and Pike GB. MRI-based myelin water imaging: A technical review. Magn Reson Med. 2015;73(1):70-81.

38. Webb S, Munro CA, Midha R, and Stanisz GJ. Is multicomponent T2 a good measure of myelin content in peripheral nerve? Magn Reson Med. 2003;49(4):638-45.

39. Gareau PJ, Rutt BK, Bowen CV, Karlik SJ, and Mitchell JR. In vivo measurements of multi-component $\mathrm{T} 2$ relaxation behaviour in guinea pig brain. Magn Reson Imaging. 1999;17(9):1319-25.

40. Gareau PJ, Rutt BK, Karlik SJ, and Mitchell JR. Magnetization transfer and multicomponent $\mathrm{T} 2$ relaxation measurements with histopathologic correlation in an experimental model of MS. J Magn Reson Imaging. 2000;11(6):586-95.

41. Moore GR, Leung E, MacKay AL, Vavasour IM, Whittall KP, Cover KS, et al. A pathology-MRI study of the short-T2 component in formalin-fixed multiple sclerosis brain. Neurology. 2000;55(10):1506-10. 
42. Kozlowski P, Liu J, Yung AC, and Tetzlaff W. High-resolution myelin water measurements in rat spinal cord. Magn Reson Med. 2008;59(4):796-802.

43. Kozlowski P, Raj D, Liu J, Lam C, Yung AC, and Tetzlaff W. Characterizing white matter damage in rat spinal cord with quantitative MRI and histology. $J$ Neurotrauma. 2008;25(6):653-76.

44. Kozlowski P, Rosicka P, Liu J, Yung AC, and Tetzlaff W. In vivo longitudinal Myelin Water Imaging in rat spinal cord following dorsal column transection injury. Magn Reson Imaging. 2014;32(3):250-8.

45. Chen HS, Holmes N, Liu J, Tetzlaff W, and Kozlowski P. Validating myelin water imaging with transmission electron microscopy in a rat spinal cord injury model. Neuroimage. 2017;153:122-30.

46. Field-Fote EC, and Tepavac D. Improved intralimb coordination in people with incomplete spinal cord injury following training with body weight support and electrical stimulation. Phys Ther. 2002;82(7):707-15.

47. Hornby TG, Zemon DH, and Campbell D. Robotic-assisted, body-weightsupported treadmill training in individuals following motor incomplete spinal cord injury. Phys Ther. 2005;85(1):52-66.

48. Dobkin B, Apple D, Barbeau H, Basso M, Behrman A, Deforge D, et al. Weightsupported treadmill vs over-ground training for walking after acute incomplete SCI. Neurology. 2006;66(4):484-93.

49. Musselman KE, Fouad K, Misiaszek JE, and Yang JF. Training of walking skills overground and on the treadmill: case series on individuals with incomplete spinal cord injury. Phys Ther. 2009;89(6):601-11. 
medRxiv preprint doi: https://doi.org/10.1101/2020.04.27.20079970; this version posted April 29, 2020. The copyright holder for this preprint

(which was not certified by peer review) is the author/funder, who has granted medRxiv a license to display the preprint in perpetuity.

All rights reserved. No reuse allowed without permission.

50. Harkema SJ, Schmidt-Read M, Lorenz DJ, Edgerton VR, and Behrman AL. Balance and ambulation improvements in individuals with chronic incomplete spinal cord injury using locomotor training based rehabilitation. Arch Phys Med Rehabil. 2012;93(9):1508-17.

51. Buehner JJ, Forrest GF, Schmidt-Read M, White S, Tansey K, and Basso DM. Relationship between ASIA examination and functional outcomes in the NeuroRecovery Network locomotor training program. Arch Phys Med Rehabil. 2012;93(9):1530-40.

52. Leech KA, Kinnaird CR, Holleran CL, Kahn J, and Hornby TG. Effects of locomotor exercise intensity on gait performance in individuals with incomplete spinal cord injury. Phys Ther. 2016;96(12):1919-29.

53. Morrison SA, Lorenz D, Eskay CP, Forrest GF, and Basso DM. Longitudinal recovery and reduced costs after 120 sessions of locomotor training for motor incomplete spinal cord injury. Arch Phys Med Rehabil. 2018;99(3):555-62.

54. Carey JR, Bhatt E, and Nagpal A. Neuroplasticity promoted by task complexity. Exerc Sport Sci Rev. 2005;33(1):24-31.

55. Wulf G, and Shea $\mathrm{CH}$. Principles derived from the study of simple skills do not generalize to complex skill learning. Psychon Bull Rev. 2002;9(2):185-211.

56. Lay AN, Hass CJ, and Gregor RJ. The effects of sloped surfaces on locomotion: a kinematic and kinetic analysis. J Biomech. 2006;39(9):1621-8.

57. Lay AN, Hass CJ, Richard Nichols T, and Gregor RJ. The effects of sloped surfaces on locomotion: an electromyographic analysis. J Biomech. 2007;40(6):1276-85. 
58. Gottschall JS, and Nichols TR. Neuromuscular strategies for the transitions between level and hill surfaces during walking. Philos Trans $R$ Soc Lond B Biol Sci. $2011 ; 366(1570): 1565-79$.

59. Montgomery JR, and Grabowski AM. The contributions of ankle, knee and hip joint work to individual leg work change during uphill and downhill walking over a range of speeds. $R$ Soc Open Sci. 2018;5(8):180550.

60. Alexander N, Strutzenberger G, Ameshofer LM, and Schwameder H. Lower limb joint work and joint work contribution during downhill and uphill walking at different inclinations. J Biomech. 2017;61:75-80.

61. Scaglioni-Solano P, and Aragon-Vargas LF. Age-related differences when walking downhill on different sloped terrains. Gait Posture. 2015;41(1):153-8.

62. Franz JR, and Kram R. The effects of grade and speed on leg muscle activations during walking. Gait Posture. 2012;35(1):143-7.

63. Hansen CN, Linklater W, Santiago R, Fisher LC, Moran S, Buford JA, et al. Characterization of recovered walking patterns and motor control after contusive spinal cord injury in rats. Brain Behav. 2012;2(5):541-52.

64. Enoka RM. Eccentric contractions require unique activation strategies by the nervous system. J Appl Physiol (1985). 1996;81(6):2339-46.

65. Duchateau J, and Baudry S. Insights into the neural control of eccentric contractions. J Appl Physiol (1985). 2014;116(11):1418-25.

66. Duchateau J, and Enoka RM. Neural control of lengthening contractions. $J$ Exp Biol. 2016;219(Pt 2):197-204. 
67. Fang Y, Siemionow V, Sahgal V, Xiong F, and Yue GH. Greater movementrelated cortical potential during human eccentric versus concentric muscle contractions. J Neurophysiol. 2001;86(4):1764-72.

68. Fang Y, Siemionow V, Sahgal V, Xiong F, and Yue GH. Distinct brain activation patterns for human maximal voluntary eccentric and concentric muscle actions. Brain Res. 2004;1023(2):200-12.

69. Kwon YH, and Park JW. Different cortical activation patterns during voluntary eccentric and concentric muscle contractions: an fMRI study.

NeuroRehabilitation. 2011;29(3):253-9.

70. Olsson CJ, Hedlund M, Sojka P, Lundstrom R, and Lindstrom B. Increased prefrontal activity and reduced motor cortex activity during imagined eccentric compared to concentric muscle actions. Front Hum Neurosci. 2012;6:255.

71. Yao WX, Li J, Jiang Z, Gao JH, Franklin CG, Huang Y, et al. Aging interferes central control mechanism for eccentric muscle contraction. Front Aging Neurosci. 2014;6:86.

72. Yao WX, Jiang Z, Li J, Jiang C, Franlin CG, Lancaster JL, et al. Brain Functional Connectivity Is Different during Voluntary Concentric and Eccentric Muscle Contraction. Front Physiol. 2016;7:521.

73. Hoque MM, Ardizzone MA, Sabatier M, Borich MR, and Kesar TM. Longer duration of downslope treadmill walking induces depression of H-reflexes measured during standing and walking. Neurology (ECronicon). 2018;10(8):76170. 
74. Hoque MM, Sabatier MJ, Borich M, Kesar T, and Backus D. The short-term effect of slope walking on soleus H-reflexes in people with multiple sclerosis. Neuroscience. 2018;391:73-80.

75. Hoque M, Borich M, Sabatier M, Backus D, and Kesar T. Effects of downslope walking on Soleus H-reflexes and walking function in individuals with multiple sclerosis: A preliminary study. NeuroRehabilitation. 2019;44(4):587-97.

76. Thompson AK, and Wolpaw JR. Restoring walking after spinal cord injury: operant conditioning of spinal reflexes can help. Neuroscientist. 2015;21(2):20315.

77. Thompson AK, Pomerantz FR, and Wolpaw JR. Operant conditioning of a spinal reflex can improve locomotion after spinal cord injury in humans. $J$ Neurosci. $2013 ; 33(6): 2365-75$

78. Maruhashi Y, Kitaoka K, Yoshiki Y, Nakamura R, Okano A, Nakamura K, et al. ROS scavenging activity and muscle damage prevention in eccentric exercise in rats. J Physiol Sci. 2007;57(4):211-6.

79. Smith LL, McKune AJ, Semple SJ, Sibanda E, Steel H, and Anderson R. Changes in serum cytokines after repeated bouts of downhill running. Appl Physiol Nutr Metab. 2007;32(2):233-40.

80. Worthen-Chaudhari L, Schmiedeler JP, and Basso DM. Training conditions that best reproduce the joint powers of unsupported walking. Gait \& posture. 2015;41(2):597-602.

81. Laule C, Vavasour IM, Kolind SH, Li DK, Traboulsee TL, Moore GR, et al. Magnetic resonance imaging of myelin. Neurotherapeutics. 2007;4(3):460-84. 
82. Lakhani B, Hayward KS, and Boyd LA. Hemispheric asymmetry in myelin after stroke is related to motor impairment and function. Neuroimage Clin. 2017;14:344-53.

83. Dale AM, Fischl B, and Sereno MI. Cortical surface-based analysis. I. Segmentation and surface reconstruction. Neuroimage. 1999;9(2):179-94.

84. Fischl B, and Dale AM. Measuring the thickness of the human cerebral cortex from magnetic resonance images. Proc Natl Acad Sci U S A. 2000;97(20):110505.

85. Fischl B, Liu A, and Dale AM. Automated manifold surgery: constructing geometrically accurate and topologically correct models of the human cerebral cortex. IEEE Trans Med Imaging. 2001;20(1):70-80.

86. Fischl B, Salat DH, Busa E, Albert M, Dieterich M, Haselgrove C, et al. Whole brain segmentation: automated labeling of neuroanatomical structures in the human brain. Neuron. 2002;33(3):341-55.

87. Fischl B, Salat DH, van der Kouwe AJ, Makris N, Segonne F, Quinn BT, et al. Sequence-independent segmentation of magnetic resonance images. Neuroimage. 2004;23 Suppl 1:S69-84.

88. Segonne F, Dale AM, Busa E, Glessner M, Salat D, Hahn HK, et al. A hybrid approach to the skull stripping problem in MRI. Neuroimage. 2004;22(3):106075.

89. Salat DH, Greve DN, Pacheco JL, Quinn BT, Helmer KG, Buckner RL, et al. Regional white matter volume differences in nondemented aging and Alzheimer's disease. Neuroimage. 2009;44(4):1247-58. 
90. Reuter M, Rosas HD, and Fischl B. Highly accurate inverse consistent registration: a robust approach. Neuroimage. 2010;53(4):1181-96.

91. Reuter M, Schmansky NJ, Rosas HD, and Fischl B. Within-subject template estimation for unbiased longitudinal image analysis. Neuroimage. 2012;61(4):1402-18.

92. Deoni SC, Dean DC, 3rd, Remer J, Dirks H, and O'Muircheartaigh J. Cortical maturation and myelination in healthy toddlers and young children. Neuroimage. 2015;115:147-61.

93. Sled JG, Zijdenbos AP, and Evans AC. A nonparametric method for automatic correction of intensity nonuniformity in MRI data. IEEE Trans Med Imaging. $1998 ; 17(1): 87-97$.

94. Segonne F, Pacheco J, and Fischl B. Geometrically accurate topology-correction of cortical surfaces using nonseparating loops. IEEE Trans Med Imaging. 2007;26(4):518-29.

95. Dale AM, and Sereno MI. Improved Localizadon of Cortical Activity by Combining EEG and MEG with MRI Cortical Surface Reconstruction: A Linear Approach. J Cogn Neurosci. 1993;5(2):162-76.

96. Gronenschild EH, Habets P, Jacobs HI, Mengelers R, Rozendaal N, van Os J, et al. The effects of FreeSurfer version, workstation type, and Macintosh operating system version on anatomical volume and cortical thickness measurements. PLoS One. 2012;7(6):e38234. 
97. Liu H, Ljungberg E, Dvorak AV, Lee LE, Yik JT, MacMillan EL, et al. Myelin water fraction and intra/extracellular water geometric mean T2 normative atlases for the cervical spinal cord from 3T MRI. J Neuroimaging. 2020;30(1):50-7.

98. Yiannakas MC, Mustafa AM, De Leener B, Kearney H, Tur C, Altmann DR, et al. Fully automated segmentation of the cervical cord from T1-weighted MRI using PropSeg: Application to multiple sclerosis. Neuroimage Clin. 2016;10:71-7.

99. De Leener B, Levy S, Dupont SM, Fonov VS, Stikov N, Louis Collins D, et al. SCT: Spinal Cord Toolbox, an open-source software for processing spinal cord MRI data. Neuroimage. 2017;145(Pt A):24-43.

100. De Leener B, Fonov VS, Collins DL, Callot V, Stikov N, and Cohen-Adad J. PAM50: Unbiased multimodal template of the brainstem and spinal cord aligned with the ICBM152 space. Neuroimage. 2018;165:170-9.

101. Lohse KR, Wadden K, Boyd LA, and Hodges NJ. Motor skill acquisition across short and long time scales: a meta-analysis of neuroimaging data.

Neuropsychologia. 2014;59:130-41.

102. Koo TK, and Li MY. A Guideline of Selecting and Reporting Intraclass Correlation Coefficients for Reliability Research. J Chiropr Med. 2016;15(2):15563.

103. Beckerman H, Roebroeck ME, Lankhorst GJ, Becher JG, Bezemer PD, and Verbeek AL. Smallest real difference, a link between reproducibility and responsiveness. Qual Life Res. 2001;10(7):571-8. 
104. Forrest GF, Hutchinson K, Lorenz DJ, Buehner JJ, Vanhiel LR, Sisto SA, et al. Are the 10 meter and 6 minute walk tests redundant in patients with spinal cord injury? PLoS One. 2014;9(5):e94108.

105. Liu H, Rubino C, Dvorak AV, Jarrett M, Ljungberg E, Vavasour IM, et al. Myelin water atlas: a template for myelin distribution in the brain. J Neuroimaging. 2019;29(6):699-706.

106. Vavasour IM, Clark CM, Li DK, and Mackay AL. Reproducibility and reliability of MR measurements in white matter: clinical implications. Neuroimage. 2006;32(2):637-42.

107. Levesque IR, Chia CL, and Pike GB. Reproducibility of in vivo magnetic resonance imaging-based measurement of myelin water. J Magn Reson Imaging. 2010;32(1):60-8.

108. MacMillan EL, Madler B, Fichtner N, Dvorak MF, Li DK, Curt A, et al. Myelin water and $\mathrm{T}(2)$ relaxation measurements in the healthy cervical spinal cord at 3.0T: repeatability and changes with age. Neuroimage. 2011;54(2):1083-90.

109. Arshad M, Stanley JA, and Raz N. Test-retest reliability and concurrent validity of in vivo myelin content indices: Myelin water fraction and calibrated T1 w/T2 w image ratio. Hum Brain Mapp. 2017;38(4):1780-90.

110. Lee LE, Ljungberg E, Shin D, Figley CR, Vavasour IM, Rauscher A, et al. Intervendor reproducibility of myelin water imaging using a 3D gradient and spin echo sequence. Front Neurosci. 2018;12:854. 
111. Meyers SM, Vavasour IM, Madler B, Harris T, Fu E, Li DK, et al. Multicenter measurements of myelin water fraction and geometric mean T2 : intra- and intersite reproducibility. J Magn Reson Imaging. 2013;38(6):1445-53.

112. Kolind SH, Madler B, Fischer S, Li DK, and MacKay AL. Myelin water imaging: Implementation and development at 3.0T and comparison to $1.5 \mathrm{~T}$ measurements. Magn Reson Med. 2009;62(1):106-15.

113. Mount CW, and Monje M. Wrapped to adapt: experience-dependent myelination. Neuron. 2017;95(4):743-56.

114. Horky LL, Galimi F, Gage FH, and Horner PJ. Fate of endogenous stem/progenitor cells following spinal cord injury. J Comp Neurol. 2006;498(4):525-38.

115. Lytle JM, Vicini S, and Wrathall JR. Phenotypic changes in NG2+ cells after spinal cord injury. J Neurotrauma. 2006;23(12):1726-38.

116. Lytle JM, and Wrathall JR. Glial cell loss, proliferation and replacement in the contused murine spinal cord. Eur J Neurosci. 2007;25(6):1711-24.

117. Hesp ZC, Goldstein EZ, Miranda CJ, Kaspar BK, and McTigue DM. Chronic oligodendrogenesis and remyelination after spinal cord injury in mice and rats. $J$ Neurosci. 2015;35(3):1274-90.

118. McTigue DM, Wei P, and Stokes BT. Proliferation of NG2-positive cells and altered oligodendrocyte numbers in the contused rat spinal cord. $J$ Neurosci. 2001;21(10):3392-400.

119. Tripathi R, and McTigue DM. Prominent oligodendrocyte genesis along the border of spinal contusion lesions. Glia. 2007;55(7):698-711. 
120. Rabchevsky AG, Sullivan PG, and Scheff SW. Temporal-spatial dynamics in oligodendrocyte and glial progenitor cell numbers throughout ventrolateral white matter following contusion spinal cord injury. Glia. 2007;55(8):831-43.

121. Sellers DL, Maris DO, and Horner PJ. Postinjury niches induce temporal shifts in progenitor fates to direct lesion repair after spinal cord injury. $J$ Neurosci. 2009;29(20):6722-33.

122. Zai L, and Wrathall JR. Cell proliferation and replacement following contusive spinal cord injury. Glia. 2005;50:247-57.

123. Tomassy GS, Berger DR, Chen HH, Kasthuri N, Hayworth KJ, Vercelli A, et al. Distinct profiles of myelin distribution along single axons of pyramidal neurons in the neocortex. Science. 2014;344(6181):319-24.

124. Hughes EG, Orthmann-Murphy JL, Langseth AJ, and Bergles DE. Myelin remodeling through experience-dependent oligodendrogenesis in the adult somatosensory cortex. Nat Neurosci. 2018;21(5):696-706.

125. Kaller MS, Lazari A, Blanco-Duque C, Sampaio-Baptista C, and Johansen-Berg H. Myelin plasticity and behaviour-connecting the dots. Curr Opin Neurobiol. 2017;47:86-92.

126. Perrey S. Brain activation associated with eccentric movement: A narrative review of the literature. Eur J Sport Sci. 2018;18(1):75-82.

127. Boyd LA, Vidoni ED, Siengsukon CF, and Wessel BD. Manipulating time-toplan alters patterns of brain activation during the Fitts' task. Exp Brain Res. 2009;194(4):527-39. 
128. Meehan SK, Randhawa B, Wessel B, and Boyd LA. Implicit sequence-specific motor learning after subcortical stroke is associated with increased prefrontal brain activations: an fMRI study. Hum Brain Mapp. 2011;32(2):290-303.

129. Jordan MM, Berkowitz D, Hannold E, Velozo CA, and Behrman AL. Thinking through every step: how people with spinal cord injuries relearn to walk. Qual Health Res. 2013;23(8):1027-41.

130. Malik RN, Cote R, and Lam T. Sensorimotor integration of vision and proprioception for obstacle crossing in ambulatory individuals with spinal cord injury. J Neurophysiol. 2017;117(1):36-46.

131. Villiger M, Grabher P, Hepp-Reymond MC, Kiper D, Curt A, Bolliger M, et al. Relationship between structural brainstem and brain plasticity and lower-limb training in spinal cord injury: a longitudinal pilot study. Front Hum Neurosci. $2015 ; 9: 254$.

132. Dutta DJ, Woo DH, Lee PR, Pajevic S, Bukalo O, Huffman WC, et al. Regulation of myelin structure and conduction velocity by perinodal astrocytes. Proc Natl Acad Sci U S A. 2018;115(46):11832-7.

133. Lovely RG, Gregor RJ, Roy RR, and Edgerton VR. Effects of training on the recovery of full-weight-bearing stepping in the adult spinal cat. Exp Neurol. 1986;92(2):421-35.

134. Barbeau H, and Rossignol S. Recovery of locomotion after chronic spinalization in the adult cat. Brain Res. 1987;412(1):84-95.

135. Dietz V, Colombo G, and Jensen L. Locomotor activity in spinal man. Lancet. 1994;344(8932):1260-3. 
136. Wernig A, Muller S, Nanassy A, and Cagol E. Laufband therapy based on 'rules of spinal locomotion' is effective in spinal cord injured persons. The European Journal Of Neuroscience. 1995;7(4):823-9.

137. Rossignol S, Chau C, Brustein E, Belanger M, Barbeau H, and Drew T. Locomotor capacities after complete and partial lesions of the spinal cord. Acta Neurobiol Exp (Wars). 1996;56(1):449-63.

138. De Leon RD, Hodgson JA, Roy RR, and Edgerton VR. Retention of hindlimb stepping ability in adult spinal cats after the cessation of step training. $J$ Neurophysiol. 1999;81(1):85-94.

139. Filli L, and Schwab ME. Structural and functional reorganization of propriospinal connections promotes functional recovery after spinal cord injury. Neural Regen Res. 2015;10(4):509-13.

140. Schucht P, Raineteau O, Schwab ME, and Fouad K. Anatomical correlates of locomotor recovery following dorsal and ventral lesions of the rat spinal cord. Exp Neurol. 2002;176(1):143-53.

141. Loy DN, Magnuson DS, Zhang YP, Onifer SM, Mills MD, Cao QL, et al. Functional redundancy of ventral spinal locomotor pathways. $J$ Neurosci. 2002;22(1):315-23.

142. Rossignol S, Barriere G, Alluin O, and Frigon A. Re-expression of locomotor function after partial spinal cord injury. Physiology (Bethesda, Md). 2009;24:12739. 
medRxiv preprint doi: https://doi.org/10.1101/2020.04.27.20079970; this version posted April 29, 2020. The copyright holder for this preprint (which was not certified by peer review) is the author/funder, who has granted medRxiv a license to display the preprint in perpetuity. All rights reserved. No reuse allowed without permission.

143. Birkl C, Birkl-Toeglhofer AM, Endmayr V, Hoftberger R, Kasprian G, Krebs C, et al. The influence of brain iron on myelin water imaging. Neuroimage. 2019;199:545-52. 


\section{Figure 1}

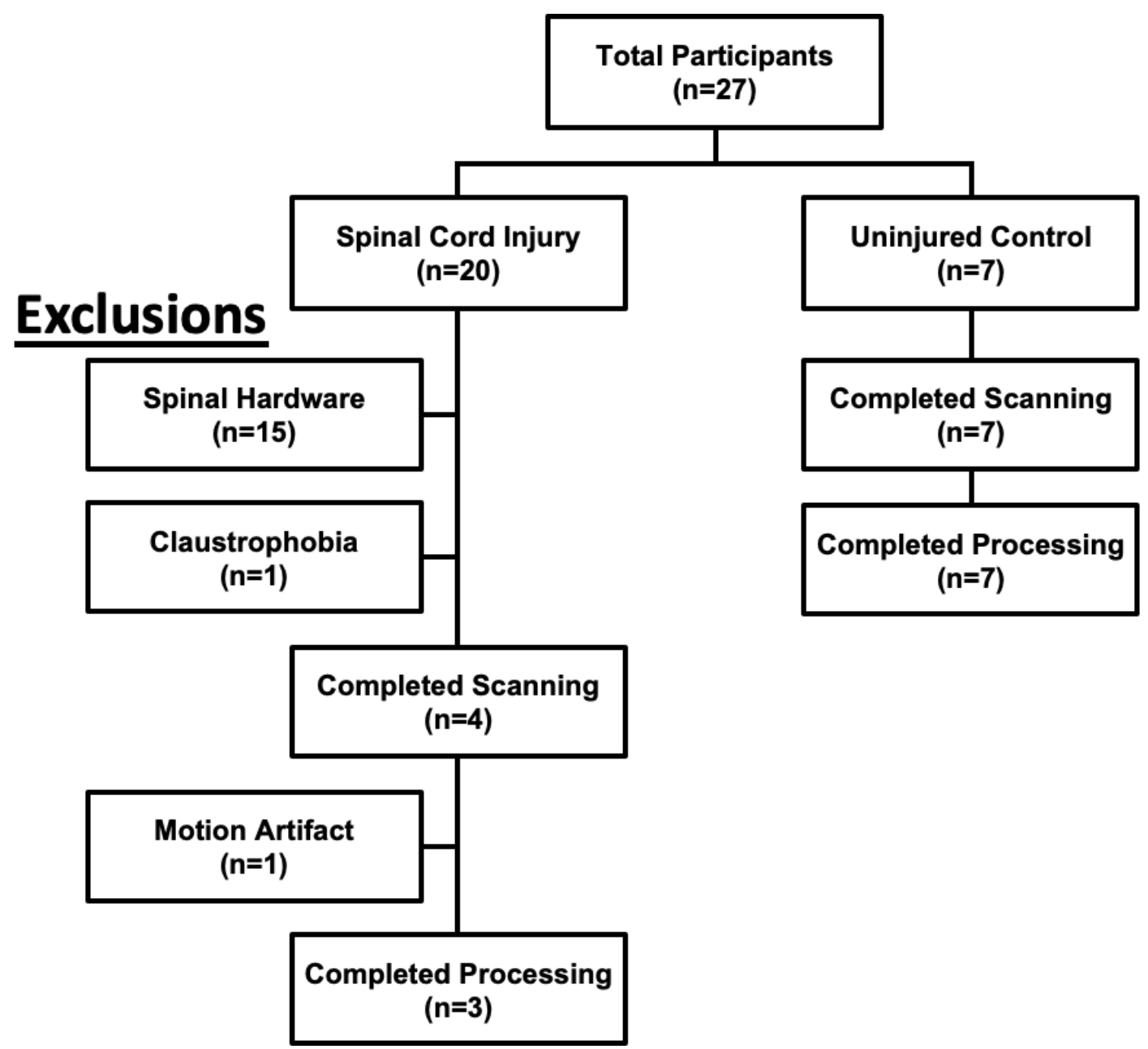

Figure 1. Disposition of participants. The timing and reason for exclusions from the MRI study are noted on the left. 
medRxiv preprint doi: https://doi.org/10.1101/2020.04.27.20079970; this version posted April 29, 2020. The copyright holder for this preprint (which was not certified by peer review) is the author/funder, who has granted medRxiv a license to display the preprint in perpetuity.

All rights reserved. No reuse allowed without permission.

\section{Figure 2}

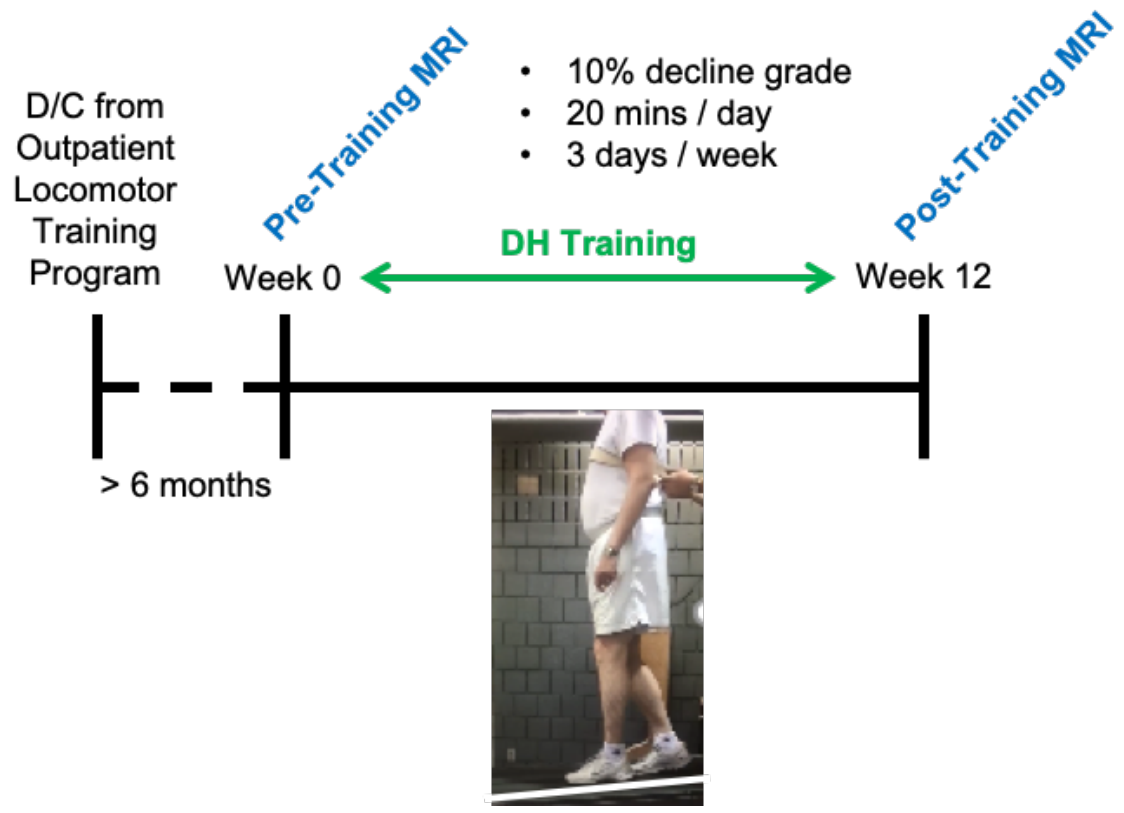

Figure 2. Experimental timeline. Individuals with incomplete SCI completed the experimental timeline described above. 
medRxiv preprint doi: https://doi.org/10.1101/2020.04.27.20079970; this version posted April 29, 2020. The copyright holder for this preprint (which was not certified by peer review) is the author/funder, who has granted medRxiv a license to display the preprint in perpetuity.

Figure 3
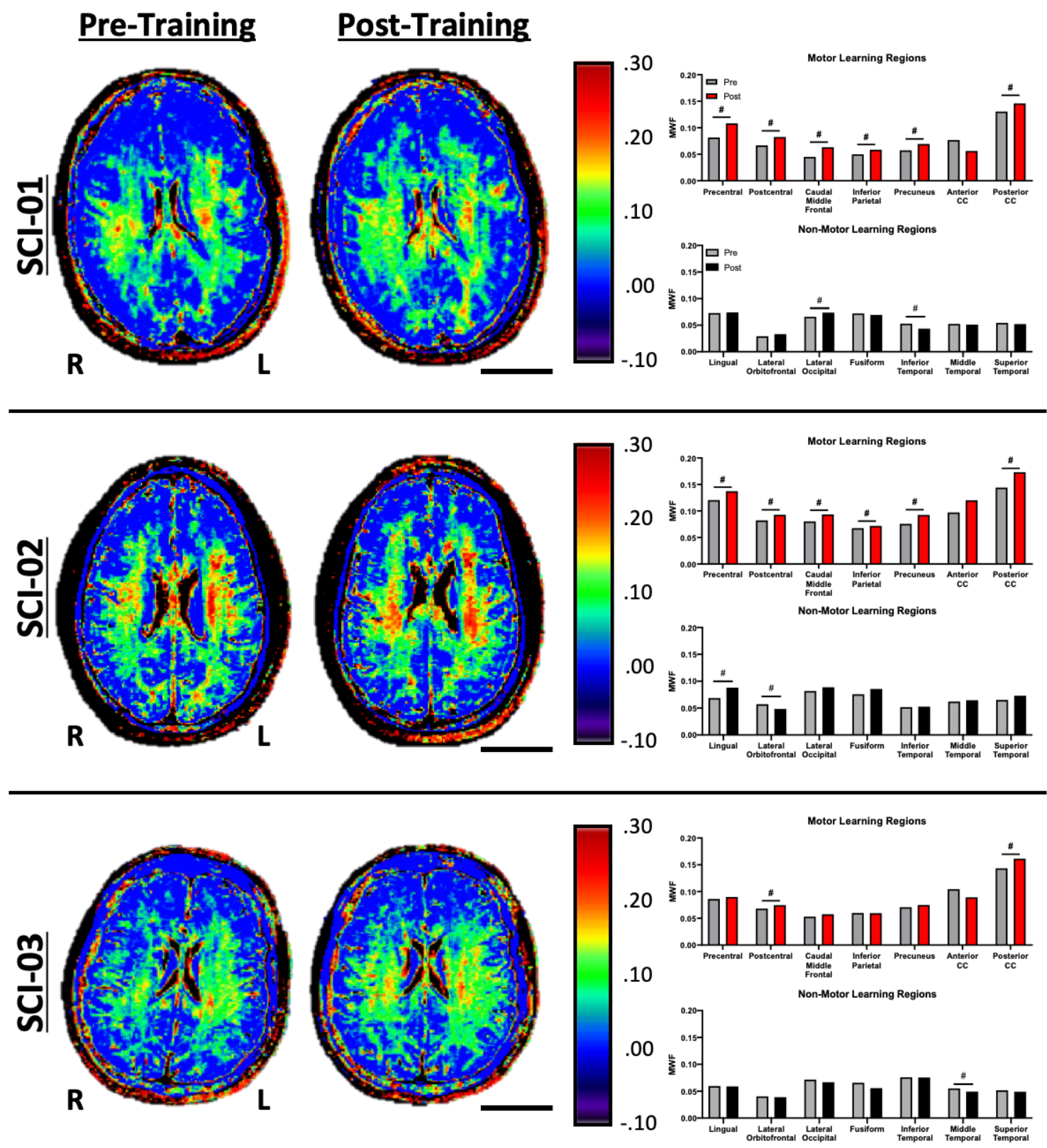

Figure 3. Downhill training increases brain MWF in individuals with chronic SCI. Preand post-downhill training MWF maps are shown from three individuals with SCI. Scale bar $=5 \mathrm{~cm}$. Quantifications of MWF within region of interest are shown. \# = individual change exceeded the minimal detectable change (MDC) for that region. 
medRxiv preprint doi: https://doi.org/10.1101/2020.04.27.20079970; this version posted April 29, 2020. The copyright holder for this preprint (which was not certified by peer review) is the author/funder, who has granted medRxiv a license to display the preprint in perpetuity.

All rights reserved. No reuse allowed without permission.

\section{Figure 4}

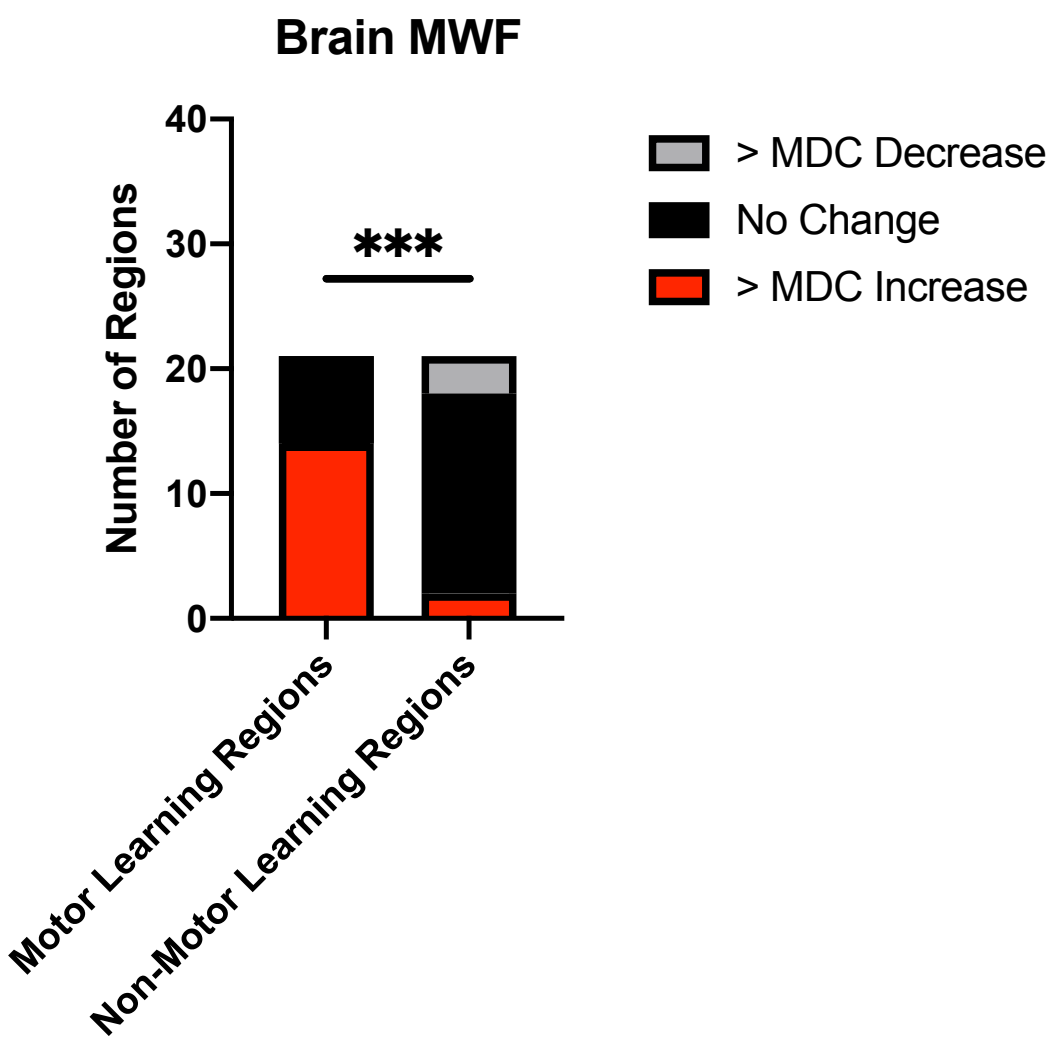

Figure 4. $M W F$ is more likely to increase in brain motor learning regions after downhill training. Quantification of individual MWF changes between motor learning and non-motor learning regions of individuals with SCI. Comparison between the number of regions demonstrating MWF increase above MDC (> MDC increase, red) and those with either no change (black) or decreased MWF ( $<$ MDC decrease, gray). Significantly more motor learning regions had MWF increase beyond MDC than non-motor learning regions ( ${ }^{* * *} \mathrm{p}<.001$; Fisher's Exact Test). 


\section{Figure 5}

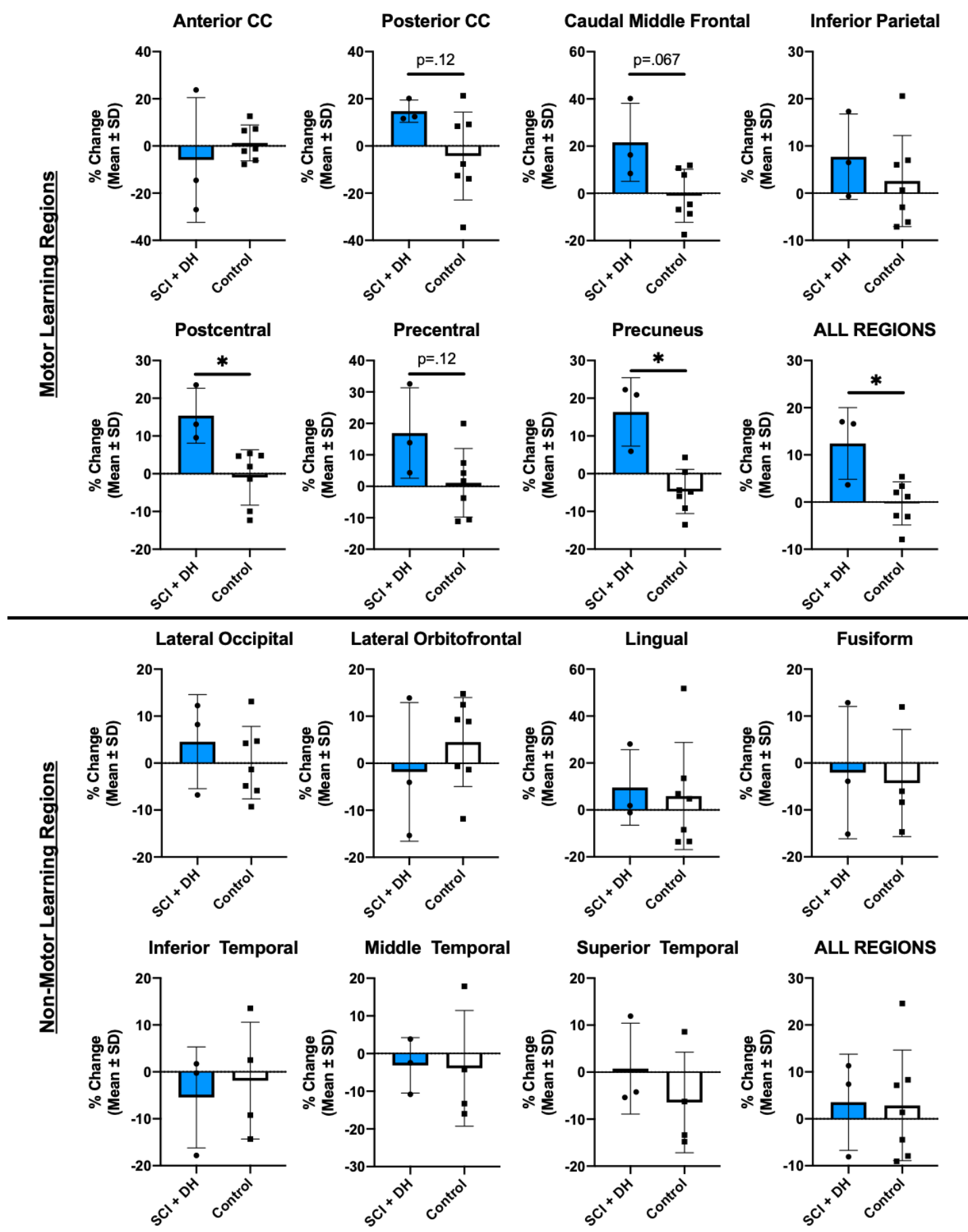

Figure 5. Changes in Brain MWF by Region of Interest. Between-group comparison of percent MWF change by region of interest associated with motor learning and nonmotor learning areas. Graphs with * indicate $\mathrm{p}<.05$ between SCI+DH and Control groups (Mann-Whitney U Test). 
Figure 6

Spinal Cord Regions
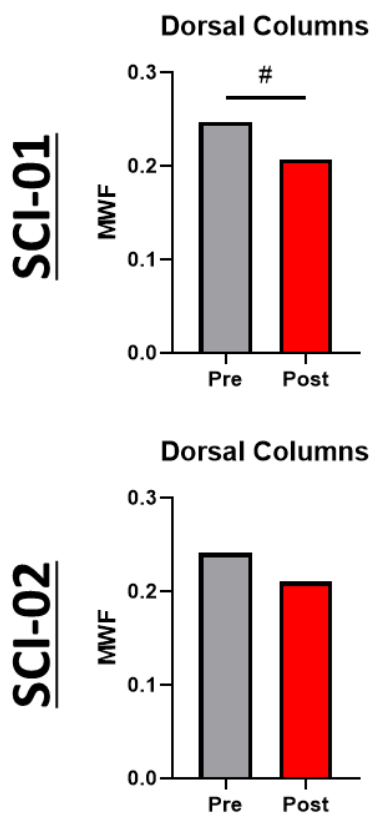

Dorsal Columns

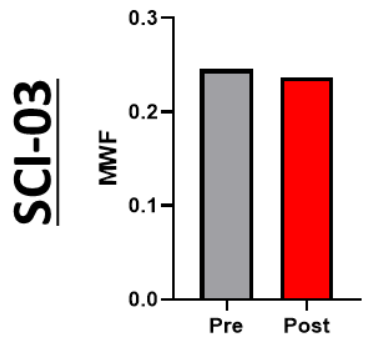

Lateral Funiculi

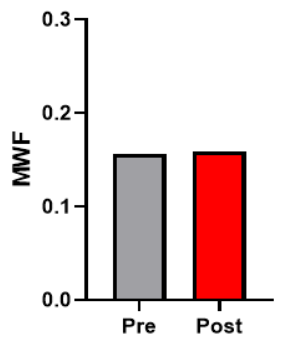

Lateral Funiculi

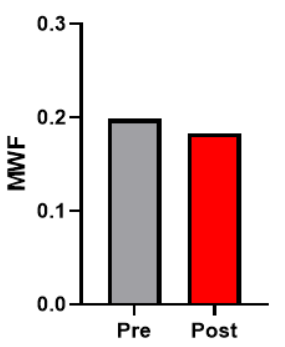

Lateral Funiculi

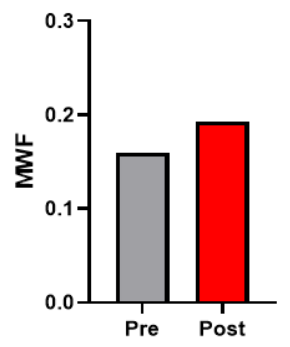

Ventral Funiculi

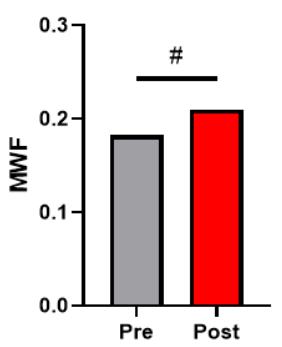

Ventral Funiculi

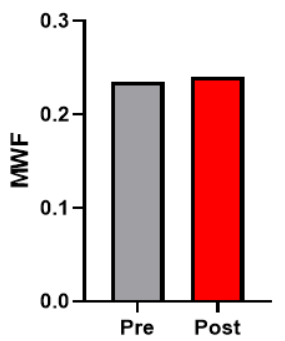

Ventral Funiculi

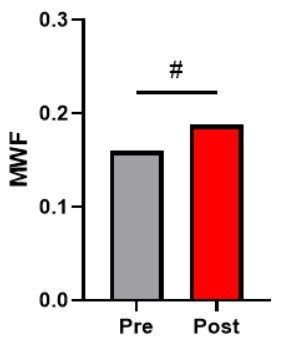

Spinal Cord

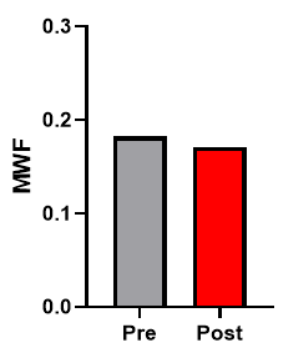

Spinal Cord

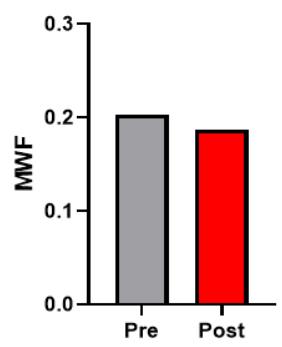

Spinal Cord

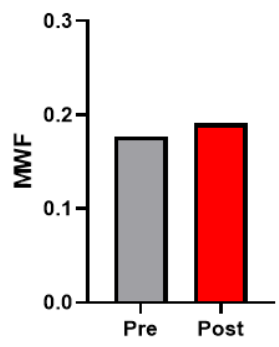

Figure 6. Individual spinal cord MWF. Quantifications of pre- and post-training MWF by white matter region and whole spinal cord at C2 are shown for each individual. Regions with \# indicate that the MWF change exceeded the MDC for that region. 


\section{Figure 7}

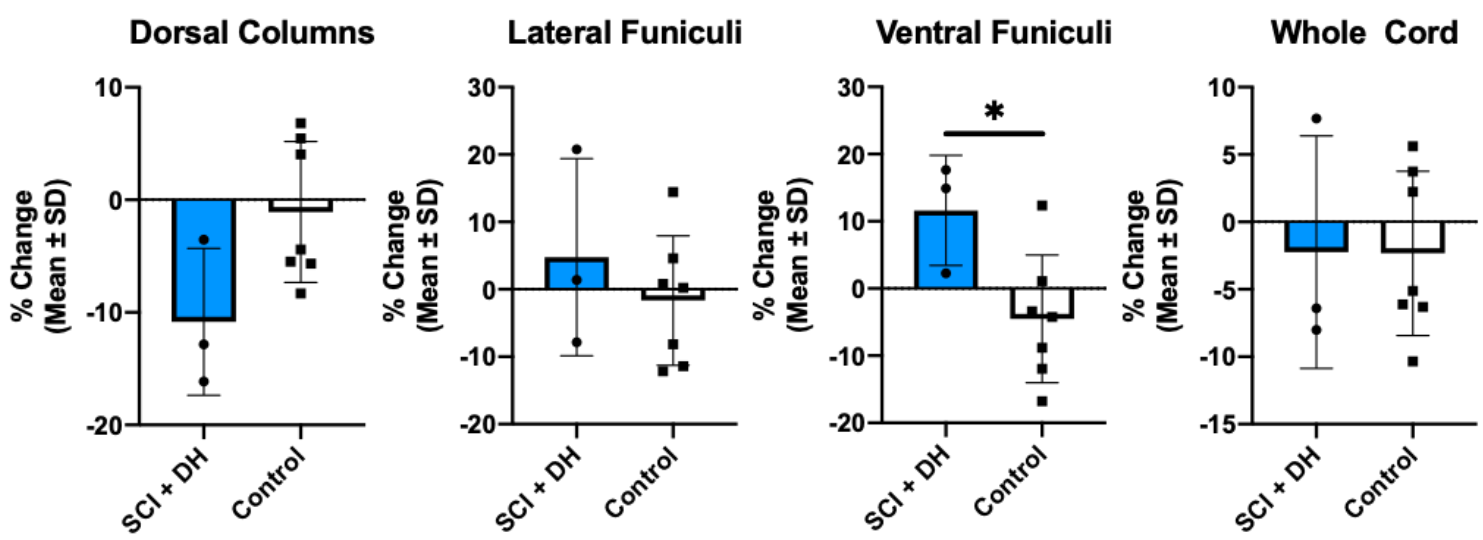

Figure 7. Changes in Spinal Cord MWF by Region. Between-group comparison of percent MWF change by white matter region and for the whole cervical spinal cord at C2. Graphs with * indicate $\mathrm{p}<.05$ between SCI+DH and Control groups (MannWhitney U Test). 


\section{Figure 8}

\section{$\underline{\text { SCl + DH Training }}$}
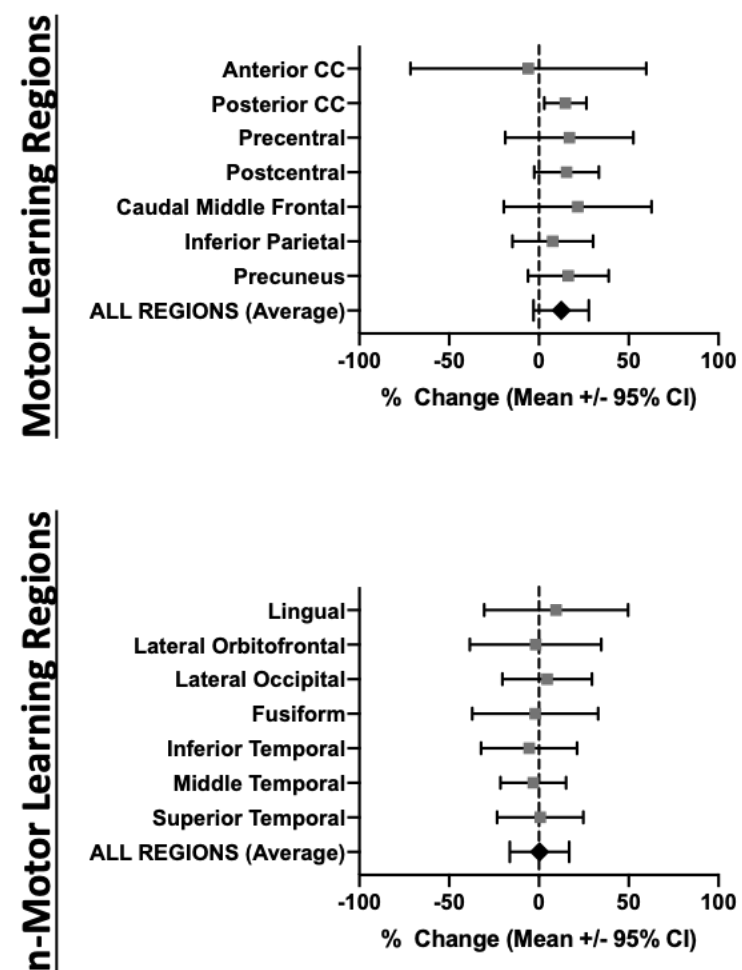

\section{Uninjured Control}
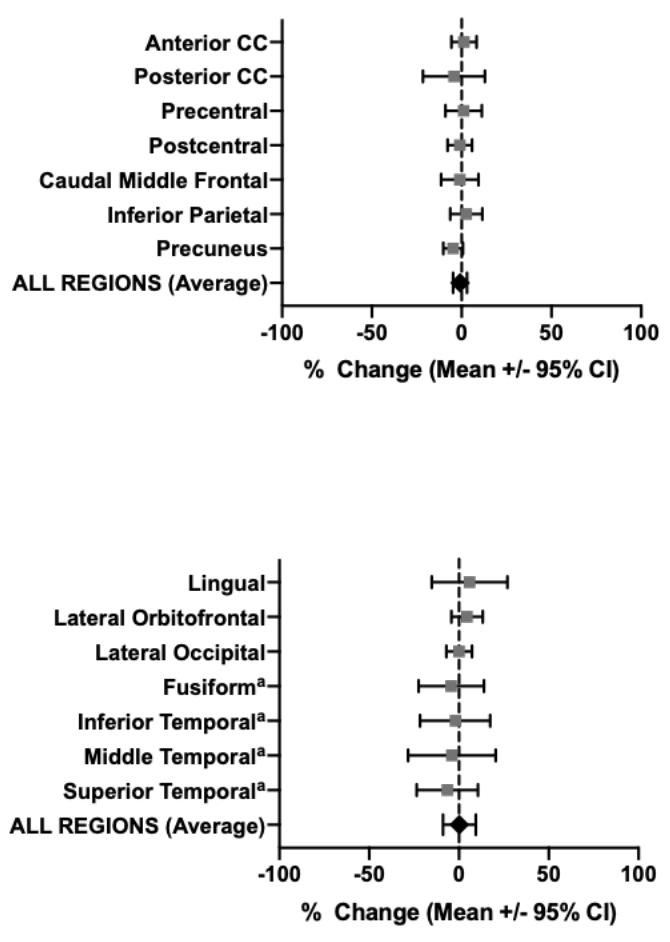

${ }^{\mathrm{a} C a l c u l a t e d}$ from $\mathrm{n}=4$ Control Subjects

Figure 8. Estimation-based approach shows specificity of brain MWF changes. Plots of the mean $\%$ changes $\pm 95 \%$ confidence interval shows a specific pattern of MWF increase in motor learning regions of individuals with SCI who underwent downhill training (rightward shift). Within downhill-trained individuals, non-motor learning regions had no change in MWF. Uninjured controls also showed no change in MWF in motor learning and non-motor learning regions. 


\section{Figure 9}

$\underline{\mathrm{SCl}+\mathrm{DH} \text { Training }}$

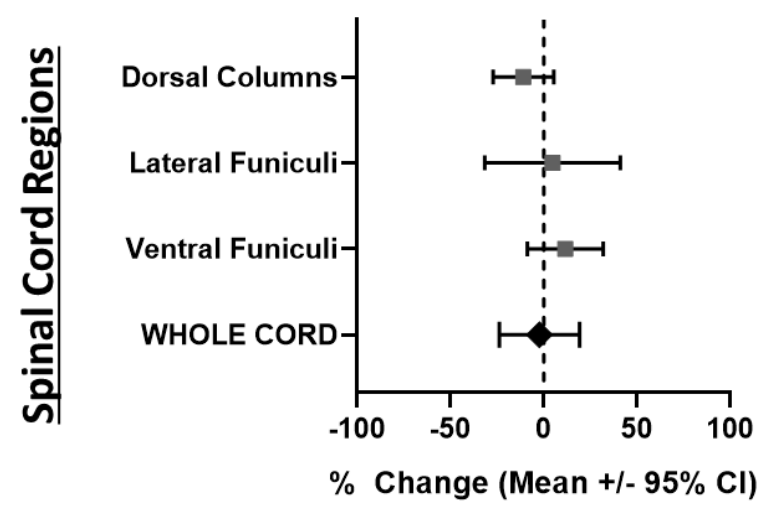

Uninjured Control

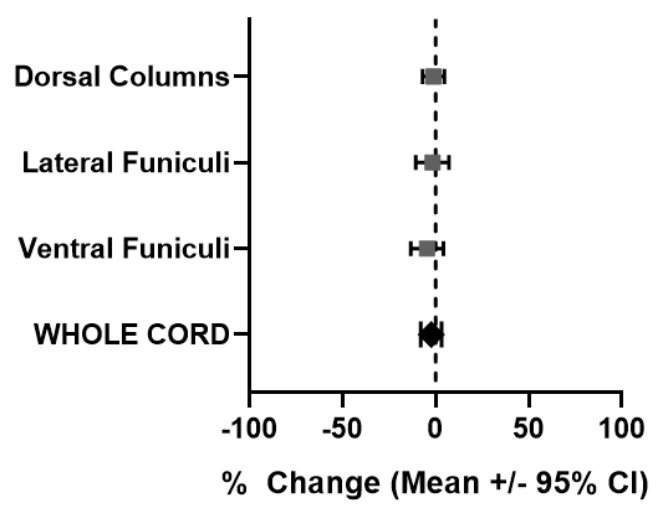

Figure 9. Estimation-based approach shows specificity of spinal cord MWF changes. Plots of the mean $\%$ changes $\pm 95 \%$ confidence interval shows a spatially-distinct pattern of MWF changes in the spinal cord after training. 
Table 1

Table 1. Demographics and clinical characteristics of participants who completed data processing.

\begin{tabular}{|c|c|c|c|c|c|c|c|c|c|c|}
\hline ID & $\begin{array}{l}\text { Age, } \\
\text { years }\end{array}$ & Sex $^{a}$ & BMI & Race & $\begin{array}{c}\text { Ethnicity } \\
\text { (Hispanic/Latino) }\end{array}$ & $\begin{array}{l}\text { Cause of } \\
\text { Injury }\end{array}$ & $\begin{array}{c}\text { Level } \\
\text { of } \\
\text { SCI }\end{array}$ & $\begin{array}{c}\text { Time } \\
\text { Since } \\
\text { Injury, } \\
\text { years }\end{array}$ & $\begin{array}{c}\text { AIS } \\
\text { Classification }\end{array}$ & $\begin{array}{l}\text { Assistive } \\
\text { Device }\end{array}$ \\
\hline SCI-01 & 35 & $\mathrm{~F}$ & 24.2 & White & No & $\begin{array}{l}\text { Epidural } \\
\text { Abscess }\end{array}$ & T6 & 6.25 & $\mathrm{D}$ & Rollator \\
\hline SCI-02 & 64 & M & 27.9 & $\begin{array}{c}\text { Black or } \\
\text { African American }\end{array}$ & Yes & Traumatic & $\mathrm{C} 1$ & 48 & $\mathrm{D}$ & Wheelchair \\
\hline SCI-03 & 63 & $\mathrm{~F}$ & 23.3 & White & No & Infection & T9 & 42 & $\mathrm{D}$ & Wheelchair \\
\hline Average & $\begin{array}{c}54 \\
(16.5) \\
\end{array}$ & - & $\begin{array}{l}25.1 \\
(2.4) \\
\end{array}$ & - & - & - & - & - & - & - \\
\hline Control-01 & 35 & $\mathrm{M}$ & 25.3 & White & No & - & - & - & - & - \\
\hline Control-02 & 66 & M & 24.7 & White & No & - & - & - & - & - \\
\hline Control-03 & 64 & $\mathrm{~F}$ & 25.8 & White & No & - & - & - & - & - \\
\hline Control-04 & 28 & $\mathrm{~F}$ & 27.1 & White & Yes & - & - & - & - & - \\
\hline Control-05 & 59 & M & 25.8 & White & No & - & - & - & - & - \\
\hline Control-06 & 34 & $\mathrm{~F}$ & 22.0 & White & Yes & - & - & - & - & - \\
\hline Control-07 & 36 & $\mathrm{~F}$ & 23.0 & White & No & - & - & - & - & - \\
\hline Average & $\begin{array}{c}46 \\
(16.2) \\
\end{array}$ & - & $\begin{array}{l}24.8 \\
(1.8) \\
\end{array}$ & - & - & - & - & - & - & - \\
\hline p-Value & .5583 & 1.0 & .9667 & .3000 & 1.0 & - & - & - & - & - \\
\hline
\end{tabular}

a Ascertained by self-report. Average values are expressed as mean (SD). Continuous variables are compared using the MannWhitney U nonparametric test. Categorical values are compared using Fisher's Exact Test. Abbreviations: AIS, ASIA

Impairment Scale; BMI, Body Mass Index; C, Cervical; F, Female; ID, Participant Identifier; M, Male; SCI, Spinal Cord Injury; T, Thoracic 
Table 2

Table 2. Within-session test-retest MWF reliability.

\begin{tabular}{|c|c|c|c|}
\hline & First MWF & Second MWF & $\underline{\text { ICC }}$ \\
\hline \multicolumn{4}{|c|}{ Brain Regions (Motor Learning) } \\
\hline Anterior Corpus Callosum & 0.095 & 0.095 & 0.907 \\
\hline Posterior Corpus Callosum & 0.127 & 0.121 & 0.738 \\
\hline Paracentral & 0.105 & 0.092 & 0.251 \\
\hline Precentral & 0.092 & 0.092 & 0.577 \\
\hline Postcentral & 0.076 & 0.075 & 0.801 \\
\hline Caudal Middle Frontal & 0.056 & 0.055 & 0.807 \\
\hline Superior Fontal & 0.039 & 0.035 & 0.342 \\
\hline Inferior Parietal & 0.058 & 0.060 & 0.742 \\
\hline Precuneus & 0.075 & 0.071 & 0.834 \\
\hline \multicolumn{4}{|c|}{ Brain Regions (Non-Motor Learning) } \\
\hline Lingual & 0.066 & 0.069 & 0.709 \\
\hline Lateral Orbitofrontal & 0.039 & 0.040 & 0.880 \\
\hline Lateral Occipital & 0.074 & 0.075 & 0.795 \\
\hline Fusiforma & 0.062 & 0.060 & 0.857 \\
\hline Inferior Temporala & 0.058 & 0.057 & 0.658 \\
\hline Middle Temporala & 0.060 & 0.058 & 0.503 \\
\hline Superior Temporala & 0.066 & 0.062 & 0.551 \\
\hline \multicolumn{4}{|l|}{ Spinal Cord Regions } \\
\hline Whole Cord & 0.219 & 0.220 & 0.898 \\
\hline Dorsal Columns & 0.259 & 0.261 & 0.917 \\
\hline Lateral Funiculi & 0.226 & 0.229 & 0.814 \\
\hline Ventral Funiculi & 0.218 & 0.212 & 0.863 \\
\hline
\end{tabular}


medRxiv preprint doi: https://doi.org/10.1101/2020.04.27.20079970; this version posted April 29, 2020. The copyright holder for this preprint (which was not certified by peer review) is the author/funder, who has granted medRxiv a license to display the preprint in perpetuity. All rights reserved. No reuse allowed without permission.

Table 3

Table 3. Minimal detectable change of MWF values

\begin{tabular}{lc}
\hline & MDC \\
\hline Brain Regions (Motor Learning) & \\
Anterior Corpus Callosum & 0.0029 \\
Posterior Corpus Callosum & 0.0122 \\
Precentral & 0.0117 \\
Postcentral & 0.0064 \\
Caudal Middle Frontal & 0.0062 \\
Inferior Parietal & 0.0041 \\
Precuneus & 0.0082 \\
\hline Brain Regions (Non-Motor Learning) & \\
Lingual & 0.0149 \\
Lateral Orbitofrontal & 0.0045 \\
Lateral Occipital & 0.0068 \\
Fusiform & 0.0109 \\
Inferior Temporal & 0.0028 \\
Middle Temporal & 0.0032 \\
Superior Temporal & 0.0040 \\
\hline Spinal Cord Regions & \\
Whole Cord & 0.0028 \\
Dorsal Columns & 0.0313 \\
Lateral Funiculi & 0.0389 \\
Ventral Funiculi & 0.0114 \\
\hline
\end{tabular}

Abbreviations: MWF, Myelin Water Fraction; MDC, Minimal Detectable Change 